\title{
Modeling portal-drained viscera and liver fluxes of essential amino acids in dairy cows
}

\author{
A. J. Fleming, ${ }^{1 *}$ (৫) H. Lapierre, ${ }^{2} \odot$ R. Martineau, ${ }^{2}$ R. R. White, ${ }^{1}$ and M. D. Hanigan ${ }^{1}$ (] \\ ${ }^{1}$ Department of Dairy Science, Virginia Tech, Blacksburg 24061 \\ ${ }^{2}$ Agricultural and Agri-Food Canada, Sherbrooke, QC, Canada J1M 0C8
}

\section{ABSTRACT}

The objective of this work was to predict essential amino acid (EAA) use and release by the portal-drained viscera (PDV) and liver of dairy cows. Previously derived equations were tested using data assembled from the literature, refit to the data, and modifications were undertaken to determine the best model for each EAA. The refitted model has the same structure as the original equations but is parameterized using a database of group means, as the original equations were derived using a single study with individual cow data and found to be biased. The PDV clearance model predicted portal vein concentrations given inputs of absorbed and arterial fluxes of EAA with root mean squared errors (RMSE) ranging from 3.3 to $12.1 \%$ of the observed means, and concordance correlation coefficients (CCC) ranging from 0.86 to 0.99 when using previously reported parameters. The reparameterized model generated from the assembled data set resulted in predictions of EAA portal vein concentrations with RMSE ranging from 3.2 to $8.6 \%$ and CCC ranging from 0.93 to 1.00 . Slope bias ranged from 12.4 to $55.3 \%$ of mean squared errors and was correlated with arterial EAA concentrations. Modifying the model to allow rate constants to vary as a function of arterial EAA concentrations reduced slope bias, resulting in RMSE ranging from 1.9 to $6.5 \%$ and CCC from 0.97 to 1.00 . Alternatively, splitting the model to account for use of EAA from absorption separately from arterial use resulted in poorer predictions and biologically infeasible parameter estimates. The liver clearance model predicted hepatic vein concentrations from arterial and portal vein input fluxes with RMSE across EAA ranging from 1.9 to $6.8 \%$ and $\mathrm{CCC}$ ranging from 0.97 to 1.00 when using reported parameters. The reparameterized model generated from the assembled data set

Received January 14, 2019.

Accepted June 8, 2019.

*Corresponding author: adelynm2@vt.edu resulted in predictions of EAA hepatic vein concentrations with RMSE ranging from 1.9 to $6.7 \%$ and CCC ranging from 0.97 to 1.00 . Significant slope bias was present for Arg, His, Lys, Phe, Thr, and Val. Altering the model to represent the clearance rate constant as a function of arterial concentrations resulted in RMSE ranging from 1.8 to $6.5 \%$ and $\mathrm{CCC}$ ranging from 0.97 to 1.00. The combination of PDV and liver clearance models provided predictions of total splanchnic use similar to those of an empirical model representing splanchnic use as a fractional proportion of absorption that had RMSE ranging from 3.0 to $8.6 \%$ and CCC ranging from 0.95 to 0.99 , with significant slope bias for the majority of EAA.

Key words: post-absorptive, essential amino acid, flow, mechanistic

\section{INTRODUCTION}

Milk is an important food source and the primary driver of revenue for dairy farms. Ruminants convert dietary energy into products such as milk more efficiently than they convert dietary N (NRC, 2001; Bequette et al., 2003). Because of their low conversion efficiency in transforming total dietary $\mathrm{N}$, dairy production from ruminants contributes significantly to environmental problems (Tamminga et al., 1995; Howarth et al., 2002). A portion of this inefficiency is due to improperly matching individual AA to animal needs (Arriola Apelo et al., 2014). An accurate representation of AA metabolism in dairy cows will allow construction of diets that more closely match absorbed AA supply to animal needs, thus improving $\mathrm{N}$ efficiency and decreasing $\mathrm{N}$ excretion.

Models have been developed to evaluate $\mathrm{N}$ metabolism in the rumen (Dijkstra et al., 1992; NRC, 2001), liver (Hanigan et al., 2004a), and mammary glands (Hanigan et al., 2000, 2001, 2002). However, to our knowledge, there have been minimal efforts to develop a more mechanistic model of the transfer of AA from the gut lumen to milk protein. Field application models represent the transfer of AA from the gut lumen to net 
protein output as a set of static conversion efficiencies, which lack accuracy and precision (NRC, 2001; White et al., 2017b).

Comparisons of estimated small intestinal disappearance to net portal appearance have shown that the portal-drained viscera (PDV) remove approximately $33 \%$ of the net AA supply (Hanigan et al., 2004b). However, the majority of this use is from arterial supply after AA have been delivered to general circulation (MacRae et al., 1997a), and thus the fractional use during absorption is considerably less. The liver also uses a significant proportion of the absorbed EAA on a net basis (Hanigan et al., 1998b), again with the arterial supply representing the vast majority of tissue input (Hanigan et al., 2004b). Because the absorbed supply represents a small fraction of the total flux through each tissue, fractional use during first pass is small (Estes, 2016), but overall use is significant due to constant recycling of AA to the splanchnic tissues (Reynolds et al., 1988; Wray-Cahen et al., 1997). Net AA use by splanchnic and mammary tissues has been shown to represent almost the entirety of net body AA use in a lactating, non-pregnant mature cow (Larsen et al., 2015). In addition to the large proportion of AA used by the splanchnic tissues, arterial AA recycling results in variable efficiency of use, which is inconsistent with a fixed transfer efficiency used in field application models (Hanigan et al., 1998a).

A process-based representation of EAA flux through the post-absorptive system may yield benefits in terms of more precise descriptions of the supply of individual AA to the mammary gland and, thus, more accurate and precise representations of milk protein production. From the above, such a representation should consider use during transit by, at minimum, splanchnic and mammary tissues, with the remaining body tissues considered in aggregate. We hypothesized that this process-based model of splanchnic use would provide more accurate and precise predictions of net EAA supplies available for peripheral tissue use than would an empirical representation, which represents tissue use as a fractional proportion of absorption without accounting for arterial supplies. Therefore, the objective of this work was to develop and test the PDV and liver components of such a process-based model.

\section{MATERIALS AND METHODS}

\section{Model Description}

An overview of a post-absorptive EAA system is depicted in Figure 1. The PDV and liver (LIV) models were constructed consistent with the needs of the overall system, considering the effects of blood entry and exit from the system, and evaluated using $\mathrm{R}$ version 3.2.2 ( $\mathrm{R}$ Core Team, 2015). The models represented the flux of 9 EAA through the tissues: Arg, His, Ile, Leu, Lys, Met, Phe, Thr, and Val. Arterial supplies to the PDV are diffuse, with no single source, and thus denoted in aggregate as PA, PDV arterial vessels. Fluxes (moles per day) were denoted as $F_{X(i)}$, where $X$ represented location - absorbed $(A b s)$, PDV arterial vessels $(P A)$, portal vein $(P V)$, hepatic artery $(H A)$, hepatic vein $(H V), \mathrm{PDV}$ use $(P D V)$, and hepatic use $(L I V)$ - and $i$ represented each EAA. In the equations below, $C_{X(i)}$ represented EAA concentrations (molar per liter) at location $X ; B F_{(X)}$ represented blood flow (liters per day) in vessel $X$ (hence, hepatic arterial, portal vein, and hepatic vein blood flows, $\boldsymbol{B F}_{\boldsymbol{H A}}, \boldsymbol{B} \boldsymbol{F}_{\boldsymbol{P} \boldsymbol{V}}$, and $\left.\boldsymbol{B} \boldsymbol{F}_{\boldsymbol{H} \boldsymbol{V}}\right)$; and $K_{T(i)}$ represented the clearance rate constant (liters per day) for the ith EAA by the tissue $T$ (PDV or LIV). Arterial sources for the different locations were assumed to be equal in concentration and thus arterial concentration was denoted as $C_{A(i)}$.

\section{PDV Model}

Transfers of EAA from the gut lumen $\left[F_{A b s(i)}\right]$ to the portal vein $\left[F_{P V(i)}\right]$, and use by the PDV $\left[F_{P D V(i)}\right]$ were calculated based on the clearance model of Hanigan et al. (2004b):

$$
\begin{gathered}
F_{P V(i)}=C_{P V(i)} \times B F_{P V}, \\
C_{P V(i)}=\frac{\left[C_{A(i)} \times B F_{P V}\right]+F_{A b s(i)}}{K_{P D V(i)}+B F_{P V}}, \\
F_{P D V(i)}=F_{A b s(i)}+\left[C_{A(i)}-C_{P V(i)}\right] \times B F_{P V},
\end{gathered}
$$

where $F_{A b s(i)}, B F_{P V}$, and $C_{A(i)}$ were required inputs. For initial evaluation, the clearance rate parameters $\left[K_{P D V(i)}\right]$ previously derived from Hanigan et al. (2004b) were used. $F_{A b s(i)}$ was the absorbed EAA supply from each diet estimated from digested RUP [grams per day; a summation across feeds $(f)$ within each diet] and microbial protein flows ( $\boldsymbol{M i T P}$, grams per day) as described by (Fleming et al., 2019):

$$
F_{A b s(i)}=\frac{\left\{\sum_{f=1}^{N_{f}}\left[D C_{R U P(f, i)} \times F_{R U P(f, i)}\right]+D C_{M i T P(i)} \times F_{M i T P(i)}\right\}}{M W_{(i)}},
$$


in which $D C_{R U P(f, i)}$ and $D C_{M i T P(i)}$ represented the digestibility coefficients (grams per gram) for each AA for RUP and MiTP, respectively, as summarized by White et al. (2017a). $M W_{(i)}$ represents molecular weight (grams per mole) for each AA. The EAA composition of MiTP was assumed to be constant, as described by Sok et al. (2017). Although there is likely diversity in the MiTP digestibility coefficient across EAA, existing data are inadequate to define such variability, and thus the MiTP digestibility coefficient for each EAA was assumed equal to that of the protein (Paz Manzano et al., 2014), which was set to a constant value of $80 \%$ (NRC, 2001). $N$ represents the number of feeds $(f)$ within each diet.

Although the total absorbed EAA supply includes EAA derived from reabsorption of endogenous protein, this was not considered in $F_{A b s(i)}$, as it represents a hidden loop within the digestive system. Endogenous protein is synthesized from arterial AA; therefore, the absorbed endogenous AA are simply replacing AA used to secrete more endogenous protein. The portion of endogenous protein that is not digested is represented as net use within $F_{P D V}$, use $(i)$.

Initial work using the clearance rate constants of Hanigan et al. (2004b) with Equation [2] indicated small but significant slope biases for predictions of portal vein concentrations and fluxes for most EAA. Refitting the model to the current data reduced the problem, but it did not completely resolve the problem, and thus alternative forms of Equation [2] were derived and tested. These included representing the clearance rate constant $\left[K_{P D V(i)}\right.$, liters per day] as a variable function of arterial blood concentrations:

$$
C_{P V(i)}=\frac{C_{A(i)} \times B F_{P V}+F_{A b s(i)}}{\left[K_{1}+K_{2} \times C_{A(i)}\right]+B F_{P V}},
$$

and representing EAA during absorption as a separate process from arterial use:

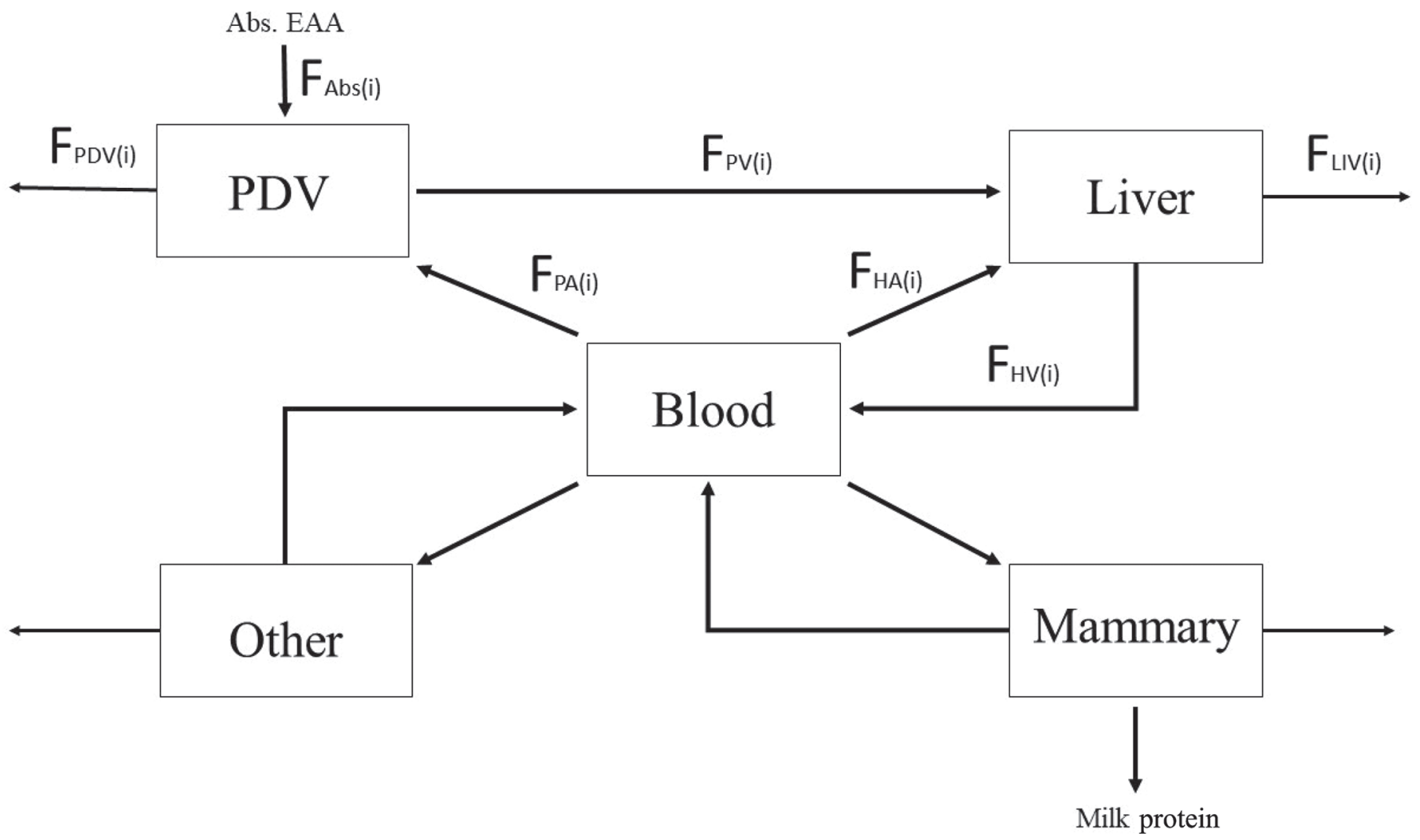

Figure 1. Schematic diagram of a post-absorptive EAA system, patterned after the model laid out in Hanigan et al. (1998b). Arrows indicate fluxes, and solid boxes denote compartments. $\mathrm{PDV}=$ portal-drained viscera; (i) denotes each of the EAA considered; $\mathrm{F}_{\mathrm{Abs}(\mathrm{i})}$ denotes the absorption of each EAA from the gut lumen; $\mathrm{F}_{\mathrm{PV}(\mathrm{i})}$ denotes the flux of each EAA in the portal vein; $\mathrm{F}_{\mathrm{PA}(\mathrm{i})}$ denotes the flux of each EAA in arterial blood entering the portal-drained viscera; $\mathrm{F}_{\mathrm{PDV}(\mathrm{i})}$ denotes the flux of each EAA used by the portal-drained viscera; $\mathrm{F}_{\mathrm{HA}(\mathrm{i})}$ denotes the flux of each EAA in the hepatic artery; $\mathrm{F}_{\mathrm{HV}(\mathrm{i})}$ denotes the flux of each EAA in the hepatic vein; $\mathrm{F}_{\mathrm{LIV}(\mathrm{i})}$ denotes the flux of each EAA used by the liver. Abs. EAA is the absorbed EAA supply to the system. 


$$
C_{P V(i)}=\frac{C_{A(i)} \times B F_{P V}}{K_{1}+B F_{P V}}+\frac{F_{A b s(i)} \times\left(1-K_{2}\right)_{i}}{B F_{P V}},
$$

where $\left(1-K_{2}\right)_{i}$ represented the fractional use (moles per mole) of each AA during absorption.

We also explored the use of an empirical, fractional use equation to assess the comparative value of the more mechanistic representation. The empirical equation represents tissue use as a fractional proportion of the absorbed supply without consideration of use from arterial supplies:

$$
C_{P V(i)}=C_{A(i)}+\frac{F_{A b s(i)} \times\left(1-f_{P D V}\right)_{i}}{B F_{P V}},
$$

where $\left(1-f_{P D V}\right)_{i}$ represents the fractional release (moles per mole) of absorbed AA.

Liver Model. Representation of the transfer of EAA from the portal vein $\left[F_{P V(i)}\right]$ to the hepatic vein $\left[F_{H V(i)}\right]$ and hepatic use $\left[F_{L I V(i)}\right]$ was based on the hepatic clearance model of Hanigan et al. (1998b):

$$
\begin{gathered}
F_{H V(i)}=C_{H V(i)} \times B F_{H V}, \\
C_{H V(i)}=\frac{\left[C_{A(i)} \times B F_{H A}\right]+\left[C_{P V(i)} \times B F_{P V}\right]}{K_{L I V(i)}+B F_{H V}}, \\
F_{L I V(i)}=\left[C_{A(i)} \times B F_{H A}\right]+\left[C_{P V(i)} \times B F_{P V}\right]-\left[C_{H V(i)} \times B F_{H V}\right],
\end{gathered}
$$

where $B F_{H V}, B F_{P V}$, and $C_{A(i)}$ were required inputs, with $B F_{H A}$ calculated as the difference between hepatic and portal vein flows $\left(B F_{H A}=B F_{H V}-B F_{P V}\right)$.

As with the PDV model, initial work using the clearance rate parameters of Hanigan et al. (1998b) with Equation [9] indicated small but significant slope biases for most EAA for predictions of hepatic vein concentrations. Refitting the model did not completely remove slope bias, and thus alternative forms of Equation [9] were derived and tested. Similar to the PDV model, an additional equation was derived representing the clearance rate constant as a variable function of $C_{A(i)}$ :

$$
C_{H V(i)}=\frac{\left[C_{A(i)} \times B F_{H A}\right]+\left[C_{P V(i)} \times B F_{P V}\right]}{\left[K_{1, H V}+K_{2, H V} \times C_{A(i)}\right]+B F_{H V}} .
$$

Splanchnic Model. Concentrations of EAA in the hepatic vein were also predicted considering absorbed and arterial supplies, using a combination of Equations $[2]$ and [9]:

$$
C_{H V(i)}=\frac{\frac{\left[C_{A(i)} \times B F_{P V}\right]+F_{A b s(i)}}{K_{P D V}+B F_{P V}} \times B F_{P V}+\left[C_{A(i)} \times B F_{H A}\right]}{K_{L I V}+B F_{H A}+B F_{P V}},
$$

where $C_{A(i)}, B F_{P V}, B F_{H A}$, and $F_{A b s(i)}$ were required inputs.

An additional empirical splanchnic model, Equation [13], was explored as a comparison to the more mechanistic approach represented by Equation [12]. As for PDV, the empirical model predicted flux and concentration changes based solely on absorbed EAA supply:

$$
C_{S P L(i)}=C_{H A(i)}+\frac{\left\{F_{A b s(i)} \times\left[1-f_{S P L(i)}\right]\right\}}{B F_{H V}},
$$

where $f_{S P L(i)}$ represented the fractional use (mole per mole) of absorbed EAA by the splanchnic bed.

Data and Statistics. Data used to evaluate and derive parameters for the PDV and LIV models consisted of 196 treatment means from 45 studies (Table 1) published in the literature from 1974 to 2012. All studies were conducted in dairy cows and were considered for inclusion if they reported hepatic arterial, portal vein, and hepatic vein blood flows $\left(B F_{H A}, B F_{P V}, B F_{H V}\right.$, liters per day), EAA concentrations, diet composition, and DMI.

All models were derived by nonlinear least squares regression using the nls function, which is part of the stats package in $\mathrm{R}$ ( $\mathrm{R}$ Core Team, 2015, version 3.2.2), unless otherwise specified. A mixed model with a random study effect using the nlmer function of the lme4 package was attempted, but it did not converge, indicating that the study effects were represented in blood flow or arterial concentrations. Therefore, random study effects were not included in the model. Resulting models were selected based on parameter significance and root mean squared errors (RMSE) and concordance correlation coefficients (CCC) associated with model predictions. Agreement between modeled and measured responses was evaluated using RMSE, mean bias, and slope bias as described by Bibby and Toutenburg (1978), and CCC as described by Lin (1989).

\section{RESULTS AND DISCUSSION}

A summary of the literature data for arterial, portal, and hepatic concentrations is presented in Table 2, and 
Table 1. Studies used for model evaluation of EAA fluxes by portaldrained viscera and liver tissues

\begin{tabular}{ll}
\hline & Citation \\
\hline Bach et al. (2000a) & Lapierre et al. (2004) \\
Bach et al. (2000b) & Larsen and Kristensen (2009) \\
Baird et al. (1974) & Larsen and Kristensen (2012) \\
Baird et al. (1975) & Lomax and Baird (1983) \\
Benson et al. (2001) & McGuire et al. (1989) \\
Berthiaume et al. (2001) & Raggio et al. (2004) \\
Berthiaume et al. (2006) & Reynolds et al. (1988) \\
Blouin et al. (2002) & Reynolds et al. (1995) \\
Casse and Rulquin (1993) & Reynolds et al. (1997) \\
Casse et al. (1994) & Reynolds et al. (1998) \\
Dalbach et al. (2011) & Reynolds et al. (1999) \\
Delgado-Elorduy et al. (2002) & Reynolds et al. (2001) \\
De Visser et al. (1997) & Reynolds et al. (2003a) \\
Doepel et al. (2007) & Reynolds et al. (2003b) \\
Doepel et al. (2009) & Reynolds et al. (unpublished \\
Girard and Desrochers (2010) & data) \\
Hammon et al. (2008) & Røjen et al. (2004) \\
Hanigan et al. (2004b) & Røjen et al. (2008) \\
Huntington (1982) & Tagari et al. (2000) \\
Huntington et al. (1983) & Tagari et al. (2004) \\
Huntington (1984) & Tagari et al. (2008) \\
Huntington and Reynolds (1986) & Whitt et al. (1996) \\
\hline
\end{tabular}

${ }^{1}$ C. Reynolds (University of Reading, Reading, United Kingdom), L. Crompton (University of Reading, Reading, United Kingdom), D. Beever (University of Reading, Reading, United Kingdom), J. Sutton (Department of Agriculture, Reading, United Kingdom), M. Lomax (University of Reading, Reading, United Kingdom), D. WrayCahen (University of Reading, Reading, United Kingdom), J. Metcalf (University of Reading, Reading, United Kingdom), B. Bequette (University of Maryland, College Park), C. Backwell (Rowett Research Institute, Aberdeen, United Kingdom), G. Lobley (Rowett Institute of Nutrition and Health, Aberdeen, United Kingdom), J. MacRae (Rowett Research Institute, Aberdeen, United Kingdom), and M. Hanigan (Virginia Tech, Blacksburg).

a summary of the data for absorbed and predicted AA fluxes and blood flow is presented in Table 3. All studies were conducted with lactating dairy cows; however, some studies also included observations from cows in late gestation. The average observed BW for the lategestation animals $(\mathrm{n}=23)$ was $570 \pm 98 \mathrm{~kg}$, with DMI of $9.0 \pm 2.2 \mathrm{~kg} / \mathrm{d}$. For the lactating cows $(\mathrm{n}=105)$, the average observed BW was $598 \pm 65 \mathrm{~kg}$ with DMI, milk production, and milk protein concentration of $17.3 \pm$ $3.53 \mathrm{~kg} / \mathrm{d}, 28.3 \pm 9.04 \mathrm{~kg} / \mathrm{d}$, and $3.3 \pm 0.4 \%$, respectively. The percentage increase in EAA concentrations from arterial to the portal vein ranged from 9 to $27 \%$, whereas the percentage increase in concentrations from arterial to the hepatic vein ranged from 6 to $20 \%$. On average, EAA concentrations in the portal vein were $5 \%$ greater than were the EAA concentration within the hepatic vein.

\section{PDV Model}

The PDV are a heterogeneous collection of tissues including the total digestive tract as well as the pan- creas, spleen, and mesenteric fat (Berthiaume et al., 2001). The implicit assumption for Equation [2] is that the PDV has a fixed activity with respect to EAA concentration and does not discriminate among absorbed and arterial supplies in terms of use. Estimates of these fixed-rate parameters were first derived for the PDV by Hanigan et al. (2004b) based on a single study. Their parameter estimates differed for all EAA, except Leu, in comparison to the parameter estimates from the refit model herein (Table 4). The relative change in mean predicted concentrations using the original parameters, as compared with those from the refit, ranged between $-11 \%$ and $+6.5 \%$. Clearance rate parameters were much greater for His, Leu, Lys, Met, Phe, Thr, and Val than previously reported, suggesting that tissue use is greater on average for those AA. Clearance rates for Arg and Ile were lower than the prior report. Differences are perhaps not surprising, as the original estimates represented a single study with cows $(611 \mathrm{~kg}$ of BW) eating roughly $16.8 \mathrm{~kg}$ of DM per day of a single diet and milking $14.8 \mathrm{~kg} / \mathrm{d}$, whereas the average BW, DMI, and milk yield for the studies used in this evaluation were $593 \pm 71.2 \mathrm{~kg}, 15.8 \pm 4.62 \mathrm{~kg} / \mathrm{d}$, and $23.2 \pm 13.6$ $\mathrm{kg} / \mathrm{d}$, respectively. However, the upper level of production for the studies used in this evaluation were 23.7 $\mathrm{kg} / \mathrm{d}$ for DMI and $47.7 \mathrm{~kg} / \mathrm{d}$ for milk yield and included the prior data. Thus, the problem should not be due to use of the models at production levels outside of the data range, which can be problematic. The combination of lower DMI and higher milk production in the current data was counterintuitive, as gut mass can be expected to scale positively with DMI (Reynolds et al., 2004), and we had previously observed lower hepatic clearance rates for nonlactating cows compared with lactating cows, presumably due to smaller liver size. These observations are consistent with reduced arterial concentrations of EAA for the current data, which is indicative of increased demand for AA by the collective tissues relative to the overall supply. Although the Hanigan et al. (2004b) data were present in the current data set, they represented only 4 treatment means and, thus, were a minor influence on the overall solutions.

Using the model and parameter estimates of Hanigan et al. (2004b) to predict $C_{P V}$ given inputs of observed arterial concentrations, estimated absorption, and observed portal blood flows resulted in RMSE ranging from 3.3 to $12.1 \%$ of the mean observed and CCC ranging from 0.86 to 0.99 (Table 5; Equation [2]). The predictions had significant mean and slope bias $(P<$ 0.05). Derivation of new rate parameters for Equation [2] removed the mean bias and resulted in RMSE ranging from 3.2 to $8.6 \%$ of the mean observed and CCC from 0.93 to 0.99 . Although the residual variance was small, the residuals displayed significant slope bias $(P$ 
Table 2. Observed arterial and venous concentrations $(\mu M)$ of EAA from the database used for model development and testing

\begin{tabular}{llrrrrr}
\hline Parameter $^{1}$ & EAA & $\mathrm{N}^{2}$ & Mean & Minimum & Maximum & SD \\
\hline$C_{A}$ & Arg & 22 & 73.9 & 52.0 & 154.9 & 23.73 \\
& His & 61 & 42.1 & 13.0 & 97.1 & 15.05 \\
& Ile & 61 & 108.4 & 36.0 & 208.1 & 33.21 \\
Leu & 63 & 130.4 & 45.0 & 233.0 & 49.23 \\
Lys & 63 & 67.5 & 31.0 & 140.0 & 21.90 \\
Met & 63 & 18.6 & 10.0 & 49.8 & 5.67 \\
& Phe & 63 & 45.6 & 1.9 & 87.3 & 11.05 \\
Thr & 61 & 89.4 & 42.0 & 169.9 & 22.66 \\
Val & 61 & 200.0 & 76.0 & 380.7 & 67.83 \\
$C_{P V}$ & Arg & 22 & 86.6 & 60.3 & 177.7 & 27.06 \\
& His & 61 & 48.0 & 16.8 & 111.2 & 16.20 \\
& Ile & 61 & 125.9 & 45.3 & 238.8 & 35.62 \\
Leu & 61 & 156.9 & 58.6 & 264.3 & 55.50 \\
Lys & 61 & 88.9 & 41.7 & 180.9 & 27.33 \\
Met & 61 & 25.5 & 13.2 & 59.0 & 6.80 \\
Phe & 61 & 60.8 & 19.7 & 112.5 & 14.03 \\
Thr & 61 & 104.4 & 48.3 & 164.4 & 23.29 \\
& Val & 61 & 219.5 & 86.7 & 405.7 & 70.72 \\
$C_{H V}$ & Arg & 22 & 78.7 & 55.9 & 154.5 & 22.02 \\
& His & 59 & 44.2 & 15.9 & 96.3 & 14.82 \\
& Ile & 59 & 121.1 & 40.3 & 212.3 & 33.93 \\
& Leu & 59 & 151.1 & 52.9 & 262.2 & 60.00 \\
Lys & 59 & 82.2 & 37.1 & 162.1 & 24.51 \\
Met & 59 & 22.1 & 10.1 & 47.0 & 5.88 \\
& Phe & 59 & 51.9 & 27.2 & 87.2 & 10.28 \\
Thr & 59 & 97.4 & 43.0 & 174.0 & 24.48 \\
Val & 59 & 213.3 & 81.9 & 401.3 & 70.15 \\
\hline
\end{tabular}

${ }^{1} C_{A}=$ arterial concentration; $C_{P V}=$ concentration in the portal vein; $C_{H V}=$ concentration in the hepatic vein. ${ }^{2} \mathrm{~N}=$ number of observations.

$<0.05$; Figure 2) indicating that there might be a better equation form to represent this relationship.

Regression analyses indicated that the residuals were negatively correlated with arterial concentrations, which implies that the tissue has decreasing clearance activity as arterial concentrations increased. This may reflect a need for a specific amount of each EAA, regardless of arterial supply. Assuming that clearance is at least partially driven by needs for tissue maintenance and secretion, such use may be expected to remain constant in the face of changes in absorbed or arterial supplies. Indeed, if endogenous secretions are driven by DMI and body size, which are both independent of EAA supply, variable tissue affinity for arterial EAA could be expected. To reflect this variation, the static clearance rate constant of Equation [2] was replaced with a variable rate function containing a fixed element $\left(K_{1}\right.$, liters per day) and an element driven by arterial concentrations $\left[K_{2}, \mathrm{~L}^{2} /(\mathrm{mol} \times \mathrm{d})\right]$, resulting in Equation [5], which was fitted to the data. The resulting parameter estimates are presented in Table 4. This approach led to reduced RMSE, ranging from 1.9 to $6.5 \%$ of the mean observed, and CCC ranging from 0.97 to 1.0 , with no significant mean or slope bias present (Table 5).
In all cases, $K_{1}$ increased relative to clearance rate parameters for Equation [2], and $K_{2}$ was negative, indicating that the tissue became less active in removing EAA as arterial concentrations increased, consistent with relatively fixed tissue requirements for EAA. There were large correlations among the fixed element parameters $\left(K_{1}\right)$ and the rate parameters driven by arterial concentrations $\left(K_{2}\right)$. However, because the standard errors (SE) were relatively low, the correlations did not appear to contribute to variance inflation. The $K_{2}$ values for Met and Phe were the largest, but the magnitude of the change elicited by arterial concentrations in overall activity is perhaps more robustly represented by the ratio of $K_{2}$ to $K_{1}$. In that case, the change in activity is proportionally large for Met and His and relatively less for branched-chain AA (BCAA). Whether the greater sensitivity to arterial His and Met reflects the importance of maintaining their concentrations in blood to avoid metabolic problems is unclear. Based on the relatively smaller $K_{2}$ values for the BCAA, PDV removal could be expected to be a relatively constant proportion of supply for those AA.

An alternative hypothesis was that biases for the simple model were associated with differential use of EAA from absorbed and arterial supplies. Absorbed 
EAA are not exposed to the activity of the entire PDV (Hanigan, 2005), whereas arterial blood is exposed to the entire tissue bed. Assuming that tissue use is constant per unit of mass, one could expect a smaller fractional extraction from the absorbed supply than from the arterial supply, given that the small intestine represents about $21 \%$ of the total gut mass in cattle
(Gibb et al., 1992). Equation [6] reflects such a potential case. However, the parameter estimates derived from fitting that model to the data suggest that all tissue use occurs from the absorbed supply, and no use occurs from arterial supplies except for Thr (Table 4). Examination of the correlation matrix indicated high correlations among the 2 sets of parameters (e.g., -0.96

Table 3. Predicted absorbed and observed blood AA fluxes used for model development and testing; predictions of absorbed fluxes calculated as described in Materials and Methods

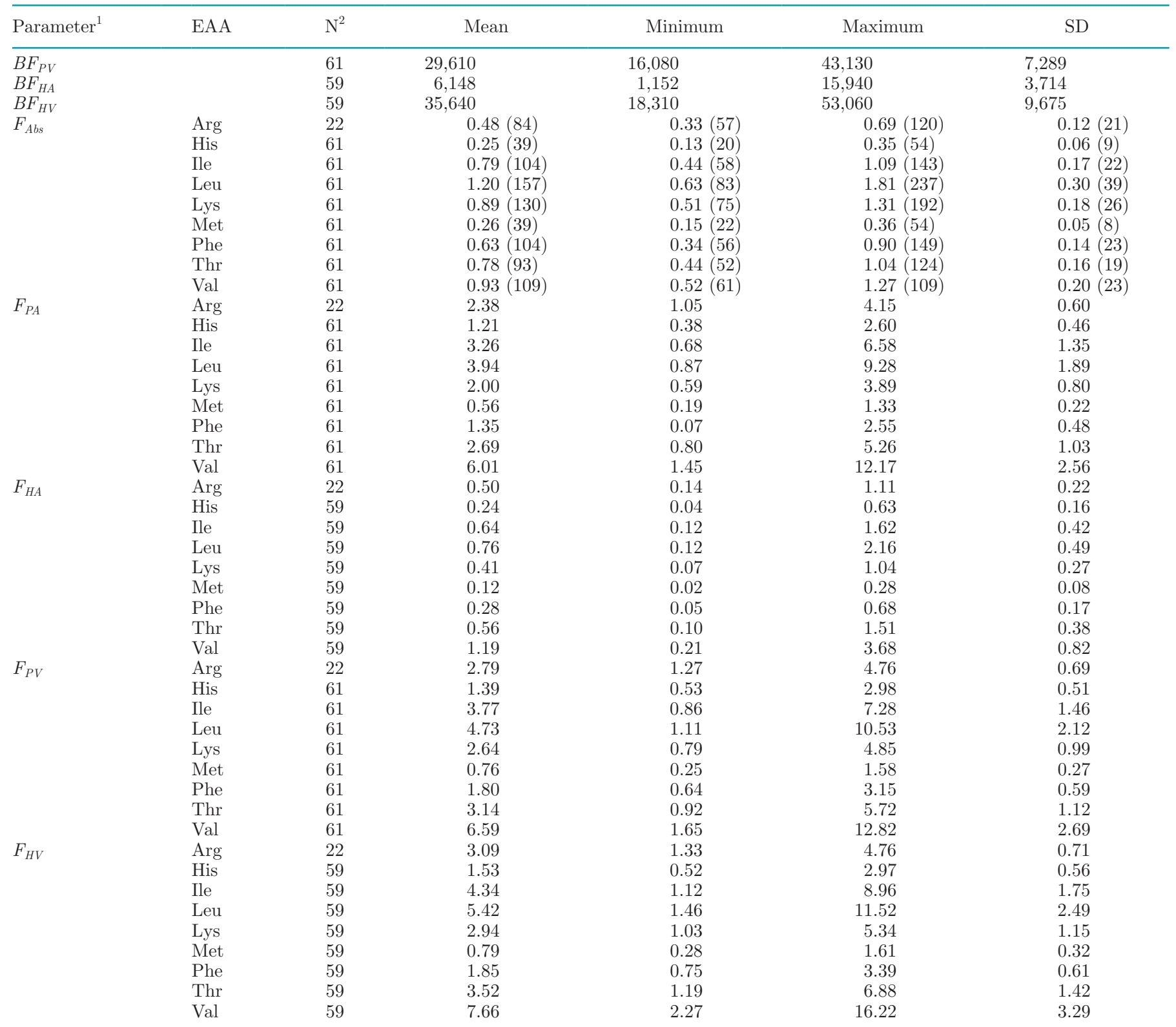

${ }^{1} B F_{P V}=$ portal vein blood flow $(\mathrm{L} / \mathrm{d}) ; B F_{H A}=$ hepatic artery blood flow $(\mathrm{L} / \mathrm{d}) ; B F_{H V}=$ hepatic vein blood flow $(\mathrm{L} / \mathrm{d}) ; F_{A b s}=$ absorbed EAA flux $\left[\mathrm{mol} / \mathrm{d}\right.$ (g/d in parentheses)] as described by Fleming et al. $(2019) ; F_{P A}=$ portal arterial flux $(\mathrm{mol} / \mathrm{d}) ; F_{H A}=$ hepatic arterial flux $(\mathrm{mol} / \mathrm{d}) ;$ $F_{P V}=$ portal vein flux $(\mathrm{mol} / \mathrm{d}) ; F_{H V}=$ hepatic vein flux $(\mathrm{mol} / \mathrm{d})$.

${ }^{2} \mathrm{~N}=$ number of observations. 


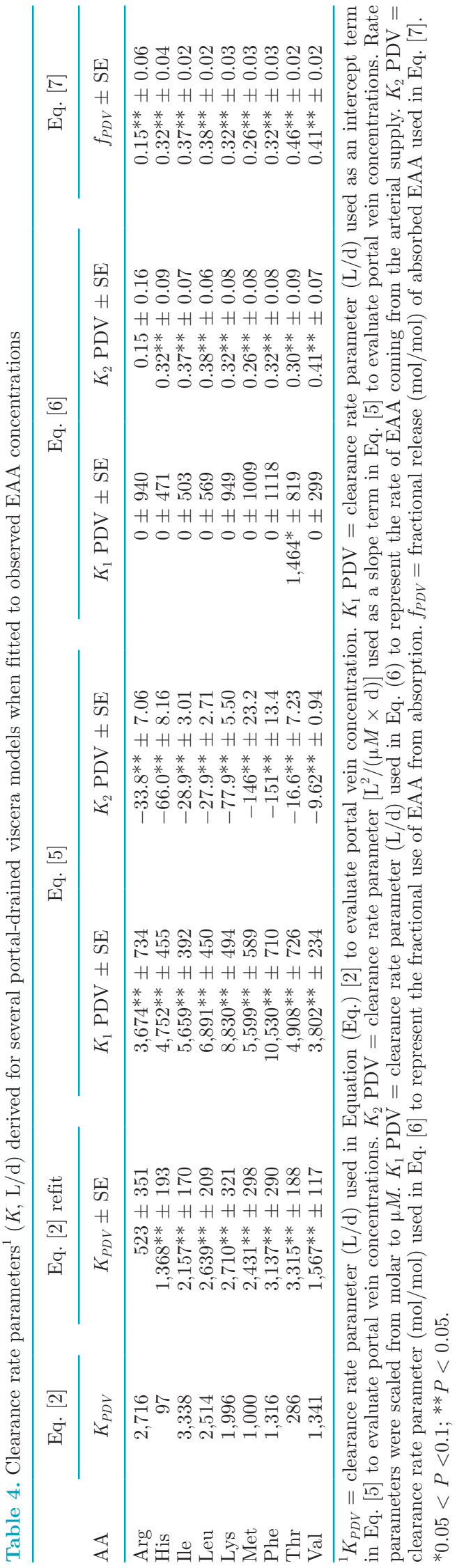

for Ile and -0.93 for Met), suggesting an identifiability problem that was also reflected in large parameter SE estimates for the arterial use parameter. Such a pattern of use is not biologically feasible, as the rumen and large intestine are not exposed to absorbed supplies that could be used to support tissue function in the absence of arterial uptake. This solution may have been driven by the use of predicted absorbed EAA supplies, which contain no random variance, whereas the measured arterial supplies contained variance. The lack of random variance in the absorbed supplies may have resulted in less prediction error, thus contributing to reduced residual error in the regression analysis when use is weighted toward absorbed.

To determine whether our revised mechanistic models were a more representative approach to evaluating portal vein concentrations than the current fixed transfer efficiency approach, Equation [7] was derived. This equation represented tissue use as a fractional proportion of absorption, ignoring any contribution to the tissue from arterial supplies. However, given the solution for Equation [7] with arterial use solving to 0, there was no functional difference between Equation [7] and Equation [6], and the results from the 2 equations were identical, having RMSE ranging from 2.5 to $8.0 \%$ of the mean observed and CCC ranging from 0.94 to 1.00. Both equations had significant slope bias for all EAA except Thr, suggesting that this approach was not as good a representation. This does not come as a surprise, because previous studies have indicated that arterial supply accounts for as much as $80 \%$ of AA use by the PDV (MacRae et al., 1997b). The statistical analysis for the predicted concentrations in PDV tissue are presented in Table 5.

Portal vein fluxes were evaluated using the above models for each EAA. Trends in the flux evaluations were similar to those for predicted concentrations. Evaluation of Equation [2] with the rate parameters derived from Hanigan et al. (2004b) provided RMSE ranging from 3 to $10 \%$ of the mean observed and CCC ranging from 0.93 to 0.99 . Significant mean bias $(>10 \%$ MSE; $P<0.05)$ occurred for all EAA except Leu, and significant slope bias ( $>8 \%$ MSE) for all except Thr. Evaluating EAA flux using refit parameters for Equation [2] resulted in RMSE ranging from 2.8 to $7.8 \%$ of mean observed and CCC ranging from 0.97 to 0.99 . The refit model reduced mean bias for all EAA but still had significant slope bias ( $>18 \%$ MSE). Using Equation [5] to predict EAA fluxes improved overall fit statistics, with RMSE ranging from 1.9 to $6.3 \%$ of mean observed and CCC ranging from 0.98 to 0.99 . We discovered no significant mean bias with this model form, but a slight slope bias remained ( $>4 \%$ MSE) for Met, and Thr. The empirical model reproduced similar 
results to those observed for Equation [5]; however, the empirical model introduced significant slope bias $(>8 \%$ MSE) for all EAA (Table 6).

Use of each EAA by the PDV was calculated using the refit model and expressed as a fraction only of the absorbed supply or of the total supply feeding the tissue (absorbed plus arterial; Table 7). Use expressed as a fraction of the absorbed supply ranged from 10 to $46 \%$, with Arg being the smallest and Thr the largest. The PDV have been interpreted to represent a barrier to efficient production, but as the majority of the use is from arterial supplies, this is not the case [see discussion by Reynolds (2006)]. Expressing use as a fraction of the total supply yields a range in use of 1.5 to $10.5 \%$, which represents single-pass use. Thus, $90 \%$ or more of the absorbed EAA are delivered to the portal vein.
One could assess model performance relative to predictions of EAA clearance by the tissue bed. Because use is small relative to total supply, RMSE would be significantly greater and CCC less. However, the overall objective of this work was to predict transfer of EAA to the mammary glands, and thus we focused on predicting release of EAA from the tissue. The RMSE were generally the greatest for Equation [2] and the least for Equation [5]. Although the overall fit statistics were good for Equation [2] and the refit of Equation [2], both had slope bias for most EAA, whereas Equation [5] exhibited no slope bias.

In conclusion, based on RMSE, MSE partitioning, CCC, and the known biology, Equation [5] best represented transfer of EAA across the PDV. Equation [2] could be used, but it has some slope bias that will feed

Table 5. Statistical summary of predictions of portal vein AA concentrations $(\mu M)$ by several models

\begin{tabular}{|c|c|c|c|c|c|c|c|c|}
\hline EAA & Eq. ${ }^{1}$ & $\mathrm{~N}^{2}$ & $\begin{array}{l}\text { Observed } \\
\text { mean }\end{array}$ & $\begin{array}{c}\text { Predicted } \\
\text { mean }\end{array}$ & $\begin{array}{c}\mathrm{RMSE}^{3} \\
(\%)\end{array}$ & $\mathrm{CCC}^{4}$ & $\begin{array}{c}\text { Mean bias } \\
(\% \text { MSE) }\end{array}$ & $\begin{array}{l}\text { Slope bias } \\
\text { (\% MSE) }\end{array}$ \\
\hline \multirow[t]{4}{*}{ Arg } & 2 & 22 & 86.6 & 81.6 & 9.1 & 0.95 & $40.4^{*}$ & $38.2^{*}$ \\
\hline & 2 -refit & & & 87.3 & 5.6 & 0.98 & 2.0 & $30.5^{*}$ \\
\hline & 5 & & & 86.3 & 3.9 & 0.99 & 0.5 & 0.3 \\
\hline & 6 and 7 & & & 86.5 & 5.3 & 0.98 & 0.0 & $24.9^{*}$ \\
\hline \multirow[t]{4}{*}{ His } & 2 & 61 & 48.0 & 50.5 & 7.6 & 0.97 & $46.7^{*}$ & 2.3 \\
\hline & 2 -refit & & & 48.2 & 5.7 & 0.98 & 0.9 & $25.2^{*}$ \\
\hline & 5 & & & 47.8 & 4.0 & 0.99 & 0.6 & 0.0 \\
\hline & 6 and 7 & & & 47.9 & 5.3 & 0.99 & 0.0 & $7.5^{*}$ \\
\hline \multirow[t]{4}{*}{ Ile } & 2 & 61 & 126 & 122 & 6.0 & 0.97 & $31.1^{*}$ & $36.7^{*}$ \\
\hline & 2 -refit & & & 126 & 4.6 & 0.99 & 0.7 & $39.9^{*}$ \\
\hline & 5 & & & 126 & 2.9 & 0.99 & 0.2 & 0.5 \\
\hline & 6 and 7 & & & 126 & 3.9 & 0.99 & 0.1 & $15.2^{*}$ \\
\hline \multirow[t]{4}{*}{ Leu } & 2 & 61 & 157 & 158 & 5.5 & 0.99 & 3.1 & $44.5^{*}$ \\
\hline & 2 -refit & & & 158 & 5.5 & 0.99 & 1.1 & $47.5^{*}$ \\
\hline & 5 & & & 157 & 3.3 & 1.00 & 0.3 & 0.0 \\
\hline & 6 and 7 & & & 157 & 4.6 & 0.99 & 0.1 & $25.4^{*}$ \\
\hline \multirow[t]{4}{*}{ Lys } & 2 & 61 & 88.9 & 91.9 & 9.0 & 0.95 & $13.3^{*}$ & $37.8^{*}$ \\
\hline & 2 -refit & & & 89.7 & 8.6 & 0.95 & 1.0 & $51.4^{*}$ \\
\hline & 5 & & & 88.6 & 4.3 & 0.99 & 0.9 & 0.1 \\
\hline & 6 and 7 & & & 88.5 & 7.3 & 0.97 & 0.4 & $37.5^{*}$ \\
\hline \multirow[t]{4}{*}{ Met } & 2 & 61 & 25.5 & 26.8 & 9.7 & 0.92 & $28.4^{*}$ & $10.2^{*}$ \\
\hline & 2 -refit & & & 25.5 & 8.1 & 0.94 & 0.0 & $32.1^{*}$ \\
\hline & 5 & & & 25.3 & 6.5 & 0.97 & 0.8 & 1.1 \\
\hline & 6 and 7 & & & 25.4 & 8.0 & 0.95 & 0.1 & $11.2^{*}$ \\
\hline \multirow[t]{4}{*}{ Phe } & 2 & 61 & 60.8 & 64.6 & 10.0 & 0.89 & $38.4^{*}$ & $10.2^{*}$ \\
\hline & 2 -refit & & & 60.8 & 7.5 & 0.93 & 0.0 & $32.1^{*}$ \\
\hline & 5 & & & 60.5 & 4.6 & 0.98 & 1.5 & 1.1 \\
\hline & 6 and 7 & & & 60.5 & 7.3 & 0.94 & 0.4 & $11.2^{*}$ \\
\hline \multirow[t]{4}{*}{ Thr } & 2 & 61 & 104 & 115 & 12.1 & 0.86 & $75.7^{*}$ & 0.2 \\
\hline & 2 -refit & & & 104 & 4.8 & 0.97 & 0.1 & $12.4^{*}$ \\
\hline & 5 & & & 104 & 4.5 & 0.98 & 0.4 & 1.0 \\
\hline & 6 and 7 & & & 104 & 5.0 & 0.97 & 0.2 & 0.0 \\
\hline \multirow[t]{4}{*}{ Val } & 2 & 61 & 219 & 222 & 3.3 & 0.99 & $13.1^{*}$ & $44.0^{*}$ \\
\hline & 2 -refit & & & 220 & 3.2 & 0.99 & 1.8 & $55.3^{*}$ \\
\hline & 5 & & & 219 & 1.9 & 1.00 & 0.1 & 0.2 \\
\hline & 6 and 7 & & & 219 & 2.5 & 1.00 & 0.0 & $20.4^{*}$ \\
\hline
\end{tabular}

${ }^{1}$ Eq. = equation used to calculate the concentration of the portal vein. Equation [2] was derived by Hanigan et al. (2004b).

${ }^{2} \mathrm{~N}=$ number of observations.

${ }^{3} \mathrm{RMSE}=$ root mean squared error (\% of the observed mean).

${ }^{4} \mathrm{CCC}=$ concordance correlation coefficient.

${ }^{*} P \leq 0.05$; otherwise, $P>0.05$. 
forward into the liver model in an integrated prediction system. Equation [6] was not uniquely defined and solved for biologically infeasible parameters, indicating use of AA only from absorbed supply, and had variance inflation due to high correlation among parameters. Thus Equation [6] should not be adopted for further use. From a systems standpoint, use of Equation [5] prevents derivation of an analytical solution for predictions of arterial concentrations, and thus the refit of
Equation [2] may represent the best form for such use, despite the small amount of slope bias.

\section{Liver Model}

Similar to the PDV, the implicit assumption for Equation [9] was that LIV had a fixed activity with respect to EAA removal and does not discriminate among portal and arterial supplies in terms of use. Us-
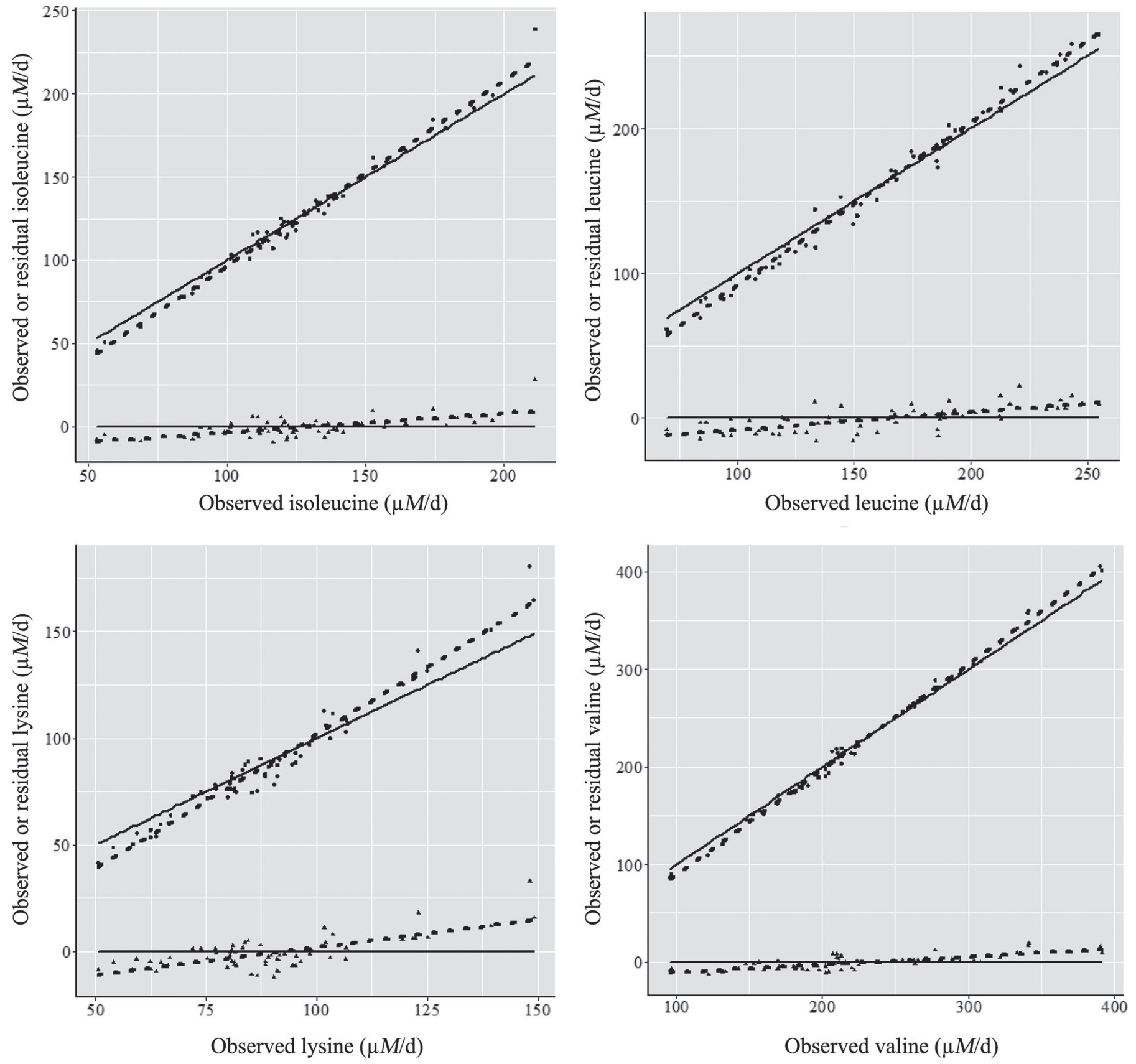

Figure 2. Residual plot of Ile, Leu, Lys, and Val portal-drained viscera concentration $(\mu M / d)$ predictions using Equation [2] when parameters were refit to the data. The solid black line represents the line of unity, and the dashed line represented the fitted model. 
Table 6. Statistical summary of portal vein AA fluxes (mol/d) predicted by several models

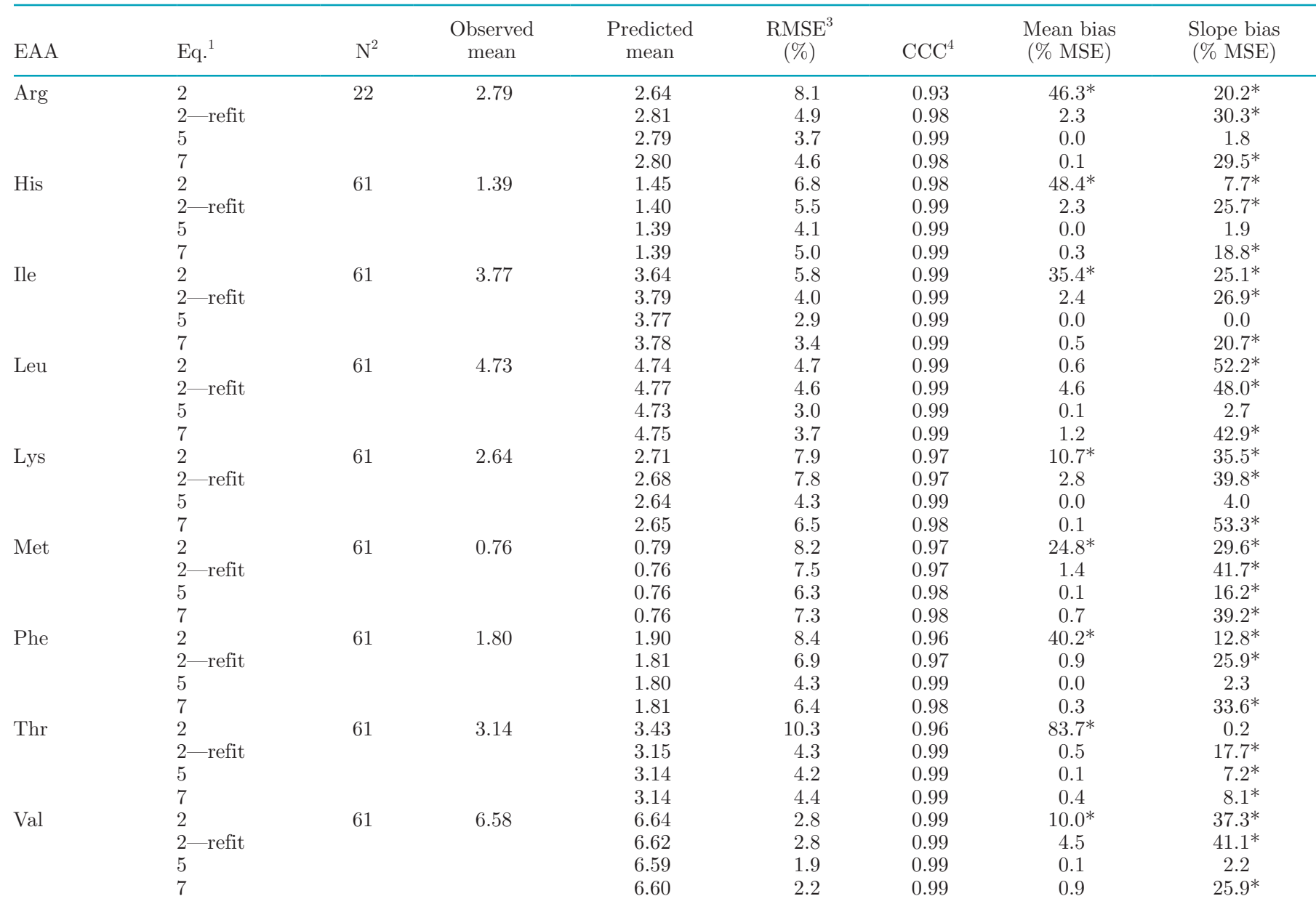

${ }^{1}$ Eq. = equation used to calculate concentration of the portal vein, which could then be used to calculate AA flux using Eq. [1]. Equation [2] was derived by Hanigan et al. (2004b).

${ }^{2} \mathrm{~N}=$ number of observations.

${ }^{3} \mathrm{RMSE}=$ root mean squared error (\% of the observed mean).

${ }^{4} \mathrm{CCC}=$ concordance correlation coefficient.

$* P \leq 0.05$; otherwise, $P>0.05$.

Table 7. Proportion of tissue EAA use, expressed as a percentage of total or absorbed EAA supplies

\begin{tabular}{|c|c|c|c|c|}
\hline \multirow[b]{2}{*}{ EAA } & \multicolumn{2}{|c|}{ PDV } & \multicolumn{2}{|c|}{ Liver } \\
\hline & Total $^{1}$ & Absorbed & Total $^{2}$ & Absorbed \\
\hline $\operatorname{Arg}$ & 1.6 & 10.3 & 7.3 & 55.2 \\
\hline His & 4.7 & 28.9 & 7.3 & 53.2 \\
\hline Ile & 7.2 & 35.5 & 0.7 & 3.4 \\
\hline Leu & 8.6 & 35.4 & 0.7 & 2.9 \\
\hline Lys & 8.8 & 28.1 & 3.9 & 12.8 \\
\hline Met & 8.0 & 25.1 & 10.4 & 34.3 \\
\hline Phe & 10.1 & 31.7 & 12.4 & 40.5 \\
\hline Thr & 10.6 & 45.8 & 4.0 & 18.0 \\
\hline Val & 5.3 & 38.0 & -0.1 & -0.4 \\
\hline
\end{tabular}

${ }^{1}$ Total $=$ proportion of tissue use coming from both arterial flux and absorption, using the refit of Equation [2]. ${ }^{2}$ Total $=$ proportion of tissue use coming from both arterial flux and EAA not used in portal-drained viscera (PDV) flux, using the refit of Equation [9]. 
Table 8. Hepatic clearance rate parameter $\operatorname{estimates}^{1}(K, \mathrm{~L} / \mathrm{d})$ for several models fitted to hepatic vein EAA concentration data

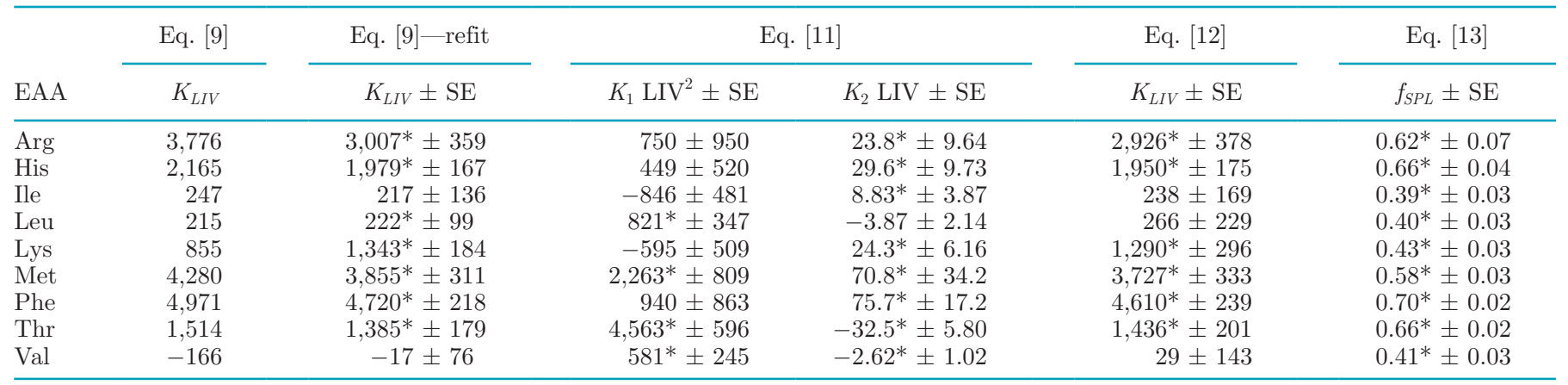

${ }^{1} K_{L I V}=$ clearance rate parameter (L/d) used in Equation (Eq.) $[9]$ to evaluate hepatic vein concentrations. $K_{1}$ LIV $=$ clearance rate parameter $(\mathrm{L} / \mathrm{d})$ used as an intercept term in Eq. [11] to evaluate hepatic vein concentrations. $K_{2} \mathrm{LIV}=$ clearance rate parameter $[(\mathrm{L} \times \mathrm{L}) / \mu M \times \mathrm{d}]$ used as a slope term in Eq. [11] to evaluate hepatic vein concentrations. $K_{L I V}=$ clearance rate parameter (L/d) used in Eq. [12] to evaluate EAA concentration in the splanchnic tissue. $f_{S P L}=$ clearance rate parameter (mol/mol) used in Eq. [13] represents the fractional release of absorbed AA in the splanchnic tissue.

${ }^{*} P \leq 0.05$; otherwise, $P>0.05$.

ing the model and parameter estimates of Hanigan et al. (1998b) to predict $C_{H V}$ given inputs of arterial and portal fluxes resulted in RMSE ranging from 1.9 to $6.8 \%$ of the mean observed and CCC ranging from 0.97 to 1.0. Original parameter estimates resulted in significant slope bias $(P<0.05)$ for several EAA (Arg, Lys, Phe, Thr, Val) when predicting hepatic vein concentrations, thus leading to significant bias in flux predictions for most EAA. Therefore, the model was refit to the data set, and a new set of rate constants were derived (Table 8), which differed for the majority of EAA compared with those initially derived by Hanigan et al. (1998b). The refit model predicted hepatic vein concentrations with RMSE ranging from 1.9 to $6.7 \%$ of the mean observed and CCC ranging from 0.97 to 1.00 (Table 9). Although the RMSE and CCC values differed only slightly from those of the original model, the mean bias improved for the majority of the EAA (especially Arg, for which there had been a significant mean bias with the original model).

Although the performance of the refit of Equation [9] appeared good, a slight slope bias remained (Table 9; Figure 3), associated with predictions of hepatic vein concentrations of Arg, His, Lys, Phe, Thr, and Val. As for PDV, the residual errors were correlated with arterial concentrations of the respective EAA. Conversion of the fixed clearance rate constant to a linear function of arterial concentrations (Equation [11]) eliminated slope bias; however, improvements in RMSE and CCC were small, and thus one might question the value of the added complexity.

In most cases, the value of $K_{2}$ was positive, indicating that the tissue became more active in removing AA as arterial concentrations increased. This was the opposite of the PDV and provides a mechanism for hepatic maintenance of circulating concentrations for those AA. The base clearance rates were reduced considerably relative to those of Equation [9], indicating that half or more of the clearance activity was variable across AA. In fact, the base rates were essentially 0 for Arg, His, the BCAA, Lys, and Phe. Only Met and Thr had substantial base rates and thus relatively less important variable rates.

It is interesting that hepatic activity for Met and Thr appears to be more consistent regardless of plasma availability, as those 2 AA flow through the lower portion of the TCA cycle via pathways that converge with propionate metabolism (Hanigan et al., 2004a). The nonsignificant or very small variable components for the BCAA would be expected, given the lack of BCAA catabolic activity by the liver (Shimomura et al., 2006). Conversely, Lobley (2003) concluded that enzymes for His, Met, and Phe catabolism are almost exclusively restricted to the hepatic tissues. It was surprising that Arg release was predicted with similar precision to that of the other EAA, as this AA is involved in the urea cycle, with significant cycling and interconversion of ornithine and Arg by the kidney and liver to maintain a supply of Arg for the rest of the body (Newsholme and Leech, 1983). One would have thought this would create more diversity in clearance rates for Arg.

In addition to arterial concentrations, residuals were regressed on intake of digestible energy (DEIn) to determine whether variation in DEIn was driving the changes in extraction kinetics. Results indicated that DEIn was not contributing significant bias to the overall EAA concentration predictions.

For the refit LIV model, the fraction of total supply of each EAA used by the tissue bed ranged from -0.1 to $12.4 \%$, with Val being the smallest and Phe the larg- 
est (Table 7). For Val, the predicted rate parameter was not significantly different from zero; therefore, the slightly negative use estimate is also not meaningful. It makes less sense to express use relative to absorbed supplies for the liver; however, doing so results in fractional use ranging from -0.4 to $55 \%$.

In addition to assessing predictions of EAA concentrations, we also evaluated predictions of EAA fluxes for each of the models. These results are presented in Table 10. Flux predictions using Equation [9] with rate parameters reported by Hanigan et al. (1998b) resulted in RMSE ranging from 2 to $7 \%$ of observed mean and CCC ranging from 0.97 to 1.0. With the original parameter estimates, significant mean bias occurred for Arg (30\% MSE), and slope bias ( $>5 \%$ MSE) was present for Arg, His, Lys, Phe, and Thr. This was expected based on observed bias when evaluating EAA concentrations. Using the rederived rate parameters resulted in similar RMSE and CCC values, reduced mean bias for Arg, but slightly increased proportions of MSE associated with slope bias ( $>7 \% \mathrm{MSE}$ ) for all EAA excluding Ile, Leu, and Met. Evaluating EAA fluxes using Equation [11] resulted in similar RMSE and CCC but reduced both mean and slope bias compared with the other LIV models.

In conclusion, based on the evaluation criteria, the best model for representing hepatic release was generally Equation [11], although all of the models adequately represented venous concentrations of BCAA (Ile, Leu, and Val) because the use of these AA by the liver is essentially 0 . In a sense, we can predict use of these AA by the tissue as 0 and assume that tissue release is equal to the inputs.

\section{Splanchnic Model}

An evaluation of predictions of hepatic vein concentrations was conducted using inputs of $F_{A b s}, C_{P A}, C_{H A}$, $B F_{P A}$, and $B F_{H A}$ and the combined PDV (Equation [2]) and LIV (Equation [9]) models (Equation [12]) or an empirical equation using only $F_{A b s}$ as an input (Equation [13]). Results are presented in Table 11. Using Equation [12] yielded RMSE ranging from 3.5 to $7.3 \%$ of observed mean and a CCC ranging from 0.95 to 0.99 . Slope bias was significant $(P \leq 0.05 ;>16 \%$ MSE) for predictions of EAA concentrations for all EAA except

Table 9. Statistical summary of hepatic vein AA concentrations $(\mu M)$ predicted by several hepatic models fitted to the data

\begin{tabular}{|c|c|c|c|c|c|c|c|c|}
\hline EAA & Eq. ${ }^{1}$ & $\mathrm{~N}^{2}$ & $\begin{array}{l}\text { Observed } \\
\text { mean }\end{array}$ & $\begin{array}{c}\text { Predicted } \\
\text { mean }\end{array}$ & $\mathrm{RMSE}^{3}$ & $\mathrm{CCC}^{4}$ & $\begin{array}{l}\text { Mean bias } \\
\text { (\% MSE) }\end{array}$ & $\begin{array}{l}\text { Slope bias } \\
\text { (\% MSE) }\end{array}$ \\
\hline \multirow[t]{3}{*}{ Arg } & 9 & 22 & 78.7 & 76.6 & 4.9 & 0.98 & $29.7^{*}$ & $14.1^{*}$ \\
\hline & 9 -refit & & & 78.1 & 4.4 & 0.99 & 3.3 & $33.6^{*}$ \\
\hline & 11 & & & 78.6 & 3.9 & 0.99 & 0.1 & 3.9 \\
\hline \multirow[t]{3}{*}{ His } & 9 & 59 & 44.2 & 43.8 & 4.1 & 0.99 & 3.4 & 5.1 \\
\hline & 9 -refit & & & 44.1 & 4.0 & 0.99 & 0.3 & $7.6^{*}$ \\
\hline & 11 & & & 44.2 & 3.7 & 0.99 & 0.2 & 0.0 \\
\hline \multirow[t]{3}{*}{ Ile } & 9 & 59 & 121 & 121 & 3.3 & 0.99 & 2.0 & 2.1 \\
\hline & 9 -refit & & & 121 & 3.3 & 0.99 & 1.3 & 2.3 \\
\hline & 11 & & & 121 & 3.2 & 0.99 & 0.4 & 1.1 \\
\hline \multirow[t]{3}{*}{ Leu } & 9 & 59 & 151 & 151 & 2.4 & 1.00 & 0.1 & 2.2 \\
\hline & 9 -refit & & & 151 & 2.4 & 1.00 & 0.2 & 2.2 \\
\hline & 11 & & & 151 & 2.3 & 1.00 & 0.9 & 0.3 \\
\hline \multirow[t]{3}{*}{ Lys } & 9 & 59 & 82.2 & 82.8 & 4.6 & 0.99 & 2.4 & $22.5^{*}$ \\
\hline & 9 -refit & & & 81.6 & 4.4 & 0.99 & 2.6 & $16.1^{*}$ \\
\hline & 11 & & & 82.0 & 3.8 & 0.99 & 0.3 & 0.0 \\
\hline \multirow[t]{3}{*}{ Met } & 9 & 59 & 22.1 & 21.8 & 6.8 & 0.97 & 4.1 & 1.8 \\
\hline & 9 -refit & & & 22.0 & 6.7 & 0.97 & 0.2 & 3.1 \\
\hline & 11 & & & 22.1 & 6.5 & 0.97 & 0.1 & 0.2 \\
\hline \multirow[t]{3}{*}{ Phe } & 9 & 59 & 51.9 & 51.4 & 4.6 & 0.98 & 4.2 & $25.6^{*}$ \\
\hline & 9 -refit & & & 51.7 & 4.5 & 0.98 & 0.4 & $28.8^{*}$ \\
\hline & 11 & & & 51.9 & 3.8 & 0.98 & 0.1 & 1.5 \\
\hline \multirow[t]{3}{*}{ Thr } & 9 & 59 & 97.4 & 97.5 & 4.1 & 0.99 & 0.1 & $13.4^{*}$ \\
\hline & 9 -refit & & & 97.9 & 4.1 & 0.99 & 1.3 & $12.5^{*}$ \\
\hline & 11 & & & 97.5 & 3.3 & 0.99 & 0.1 & 2.5 \\
\hline \multirow[t]{3}{*}{ Val } & 9 & 59 & 213 & 214 & 1.9 & 1.00 & 4.6 & 3.4 \\
\hline & 9 -refit & & & 213 & 1.9 & 1.00 & 0.0 & $6.5^{*}$ \\
\hline & 11 & & & 213 & 1.7 & 1.00 & 0.7 & 0.1 \\
\hline
\end{tabular}

${ }^{1}$ Eq. = equation used to calculate concentration of the hepatic vein. Equation [10] was derived by Hanigan et al. (1998b).

${ }^{2} \mathrm{~N}=$ number of observations.

${ }^{3} \mathrm{RMSE}=$ root mean squared error (\% of the observed mean).

${ }^{4} \mathrm{CCC}=$ concordance correlation coefficient.

${ }^{*} P \leq 0.05$; otherwise, $P>0.05$. 
Arg, which likely propagated from the slope bias of the underlying models. However, the slope was less than 0.2 $\mu \mathrm{mol} / \mathrm{L}$ and contributed very little to the MSE.

Equation [13] had a similar range in CCC, with RMSE ranging from 3.0 to $8.6 \%$, with slope bias for Arg, His, Leu, Thr, and Val. The bias associated with these 3 EAA across the splanchnic tissue was less than
$30 \%$ MSE $(<0.1 \mu \mathrm{mol} / \mathrm{L})$ and thus made a minor contribution to overall bias.

In addition to assessing predictions of hepatic vein concentrations, we also evaluated predictions of hepatic vein fluxes for each of the 2 models. These results are presented in Table 12. Using Equation [12] yielded RMSE ranging from 2.6 to $7.9 \%$ of the observed mean
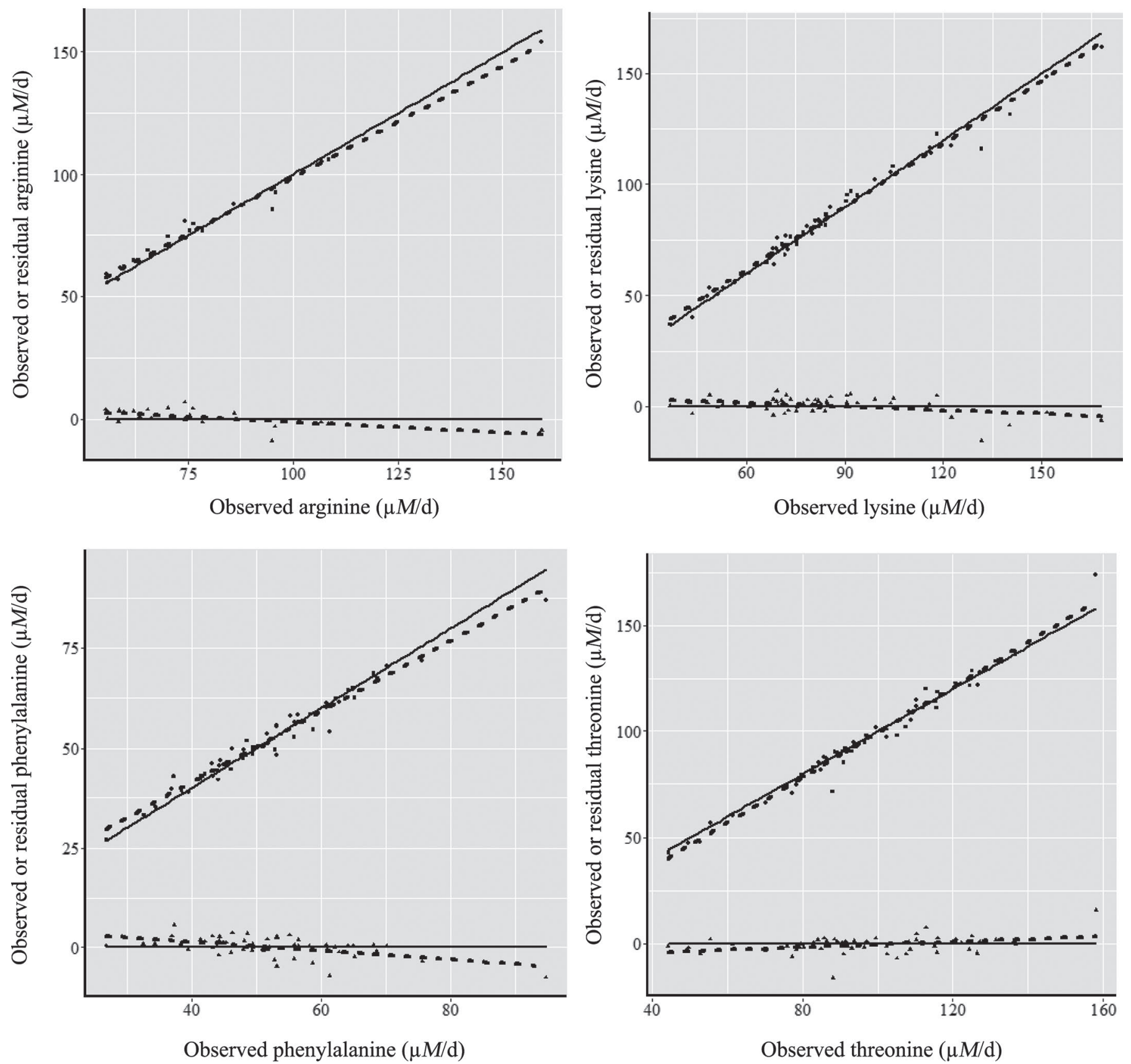

Figure 3. Residual plot of Arg, Lys, Phe, and Thr liver concentration ( $\mu M /$ d) predictions using Equation [9] when rate parameters were refit to the data. The solid black line represents the line of unity, and the dashed line represented the fitted model. 
Table 10. Statistical summary of hepatic vein fluxes $(\mathrm{mol} / \mathrm{d})$ predicted by the hepatic model ${ }^{1}$

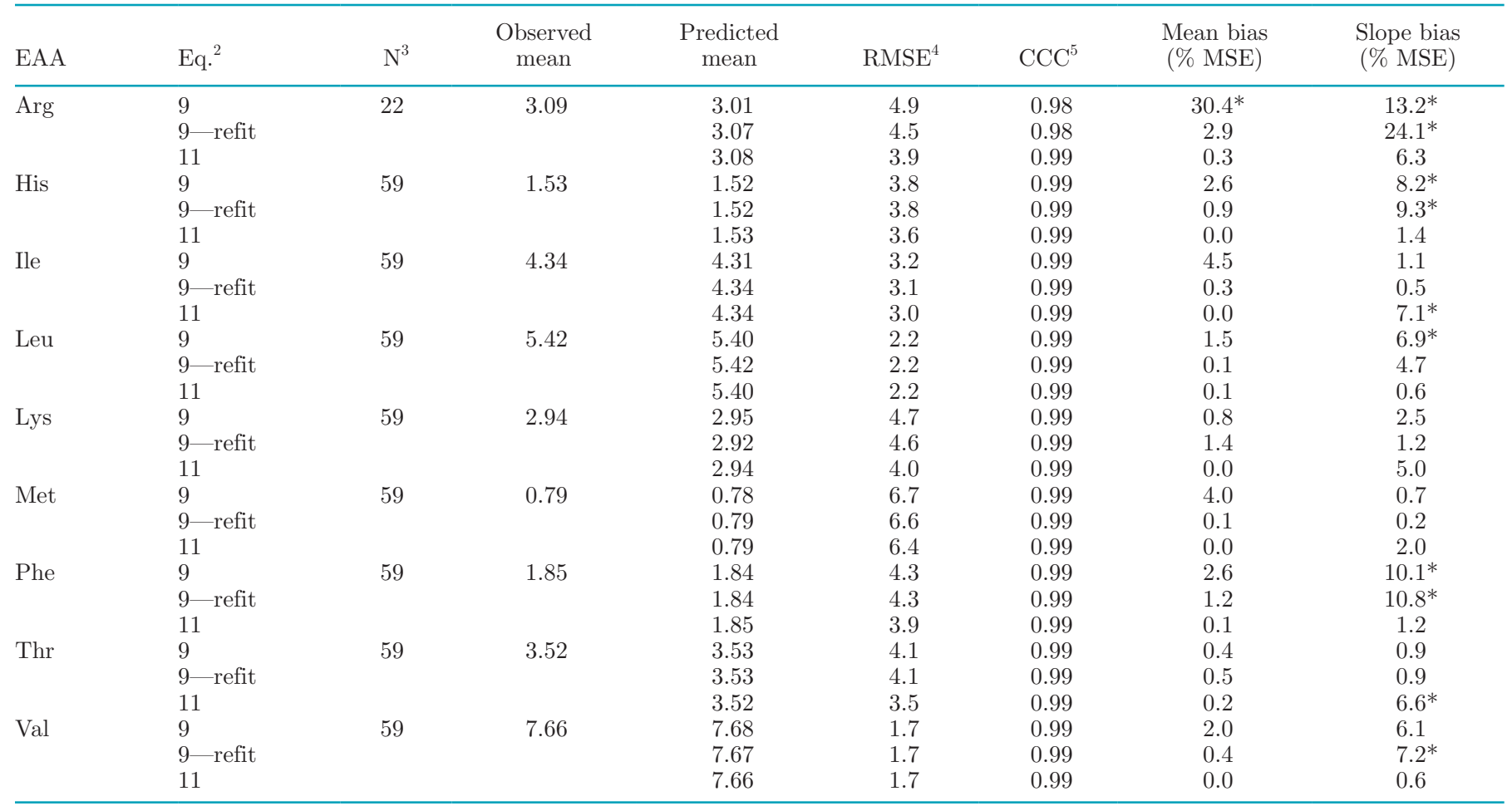

${ }^{1}$ Inputs were arterial and portal vein EAA concentrations and observed splanchnic blood flows.

${ }^{2}$ Eq. = equation used to calculate concentration of the hepatic vein. Equation [9] was derived by Hanigan et al. (1998b).

${ }^{3} \mathrm{~N}=$ number of observations.

${ }^{4} \mathrm{RMSE}=$ root mean squared error (\% of the observed mean).

${ }^{5} \mathrm{CCC}=$ concordance correlation coefficient

$* P \leq 0.05$; otherwise, $P>0.05$.

and a CCC ranging from 0.97 to 0.99 . Significant slope bias $(P \leq 0.05 ;>16 \%$ MSE $)$ occurred for all EAA except Arg and His. Equation [13] had similar values, with RMSE ranging from 1.3 to $7.4 \%$ MSE and CCC ranging from 0.98 to 0.99 . Similarly, significant slope bias $(P \leq 0.05 ;>10 \%$ MSE) occurred for all EAA except Arg. Given the prior demonstration of better performance for the underlying PDV and hepatic clearance models when clearance rates were expressed as a function of arterial AA concentrations, one should use those more complicated models for integrated splanchnic representation, but that does add complexity to the model.

We found no clear advantage to using the more mechanistic representation of the effects of blood flow and recycled arterial EAA over the simple fractional use of EAA from the absorbed stream, as there was no significant correlation between arterial EAA concentration and the predicted absorbed EAA supply. The simpler empirical representation provides an advantage, in that it does not require predictions of splanchnic blood flow (Ellis et al., 2016) or arterial concentrations. The mechanistic approach may prove to be superior when inputs other than EAA are manipulated separately from EAA. For example, BF has been observed to be related to energy intake (Ellis et al., 2016); thus, it is possible that attempts to reduce EAA supply and increase DEIn will result in aberrant predictions of the responses. The empirical model also cannot accommodate increased fractional recycling, as the post-splanchnic EAA supply approaches saturation of milk protein production. In such a case, the marginal uptake and deposition of EAA in milk protein will decline, resulting in marginal increases in arterial concentrations and recycling. The mechanistic model will respond to such changes through increased removal and disposal of the excess, whereas the empirical model will not. Thus, the mechanistic representation may provide more robust predictions over a broader range of input conditions than can be expected with the empirical representation. Hence, given the near equality of accuracy and precision of predictions, it seems prudent to select the more mechanistic representation where it can be supported. 
Table 11. Statistical summary of predicted hepatic vein EAA concentrations $(\mu M)$ using arterial and absorbed fluxes and the combined PDV and LIV models

\begin{tabular}{|c|c|c|c|c|c|c|c|c|c|}
\hline EAA & Eq. ${ }^{1}$ & $\mathrm{~N}^{2}$ & $\begin{array}{l}\text { Observed } \\
\text { mean }\end{array}$ & $\begin{array}{l}\text { Predicted } \\
\text { mean }\end{array}$ & $\mathrm{RMSE}^{3}$ & $\mathrm{CCC}^{4}$ & $\begin{array}{c}\text { Mean bias } \\
(\% \text { MSE })\end{array}$ & $\begin{array}{c}\text { Slope } \\
(\mu M / \mathrm{L}) /(\mu M / \mathrm{L})\end{array}$ & $\begin{array}{l}\text { Slope bias } \\
\text { (\% MSE) }\end{array}$ \\
\hline \multirow[t]{2}{*}{$\operatorname{Arg}$} & 12 & 22 & 78.7 & 78.7 & 4.7 & 0.98 & 0.0 & 0.0 & 0.2 \\
\hline & 13 & & & 78.5 & 5.1 & 0.98 & 0.2 & -0.1 & $29.6^{*}$ \\
\hline His & 13 & & & 44.3 & 4.9 & 0.99 & 0.2 & -0.0 & $9.2^{*}$ \\
\hline \multirow[t]{2}{*}{ Ile } & 12 & 59 & 121.0 & 121.0 & 4.1 & 0.99 & 0.0 & 0.0 & $24.2^{*}$ \\
\hline & 13 & & & 121.0 & 4.1 & 0.99 & 0.2 & 0.1 & 3.0 \\
\hline \multirow[t]{2}{*}{ Lys } & 12 & 59 & 82.2 & 82.4 & 7.1 & 0.97 & 0.1 & 0.1 & $28.5^{*}$ \\
\hline & 13 & & & 81.7 & 6.4 & 0.98 & 0.8 & 0.0 & 4.1 \\
\hline \multirow[t]{2}{*}{ Met } & 12 & 59 & 22.1 & 22.1 & 7.3 & 0.95 & 0.1 & 0.2 & $26.9^{*}$ \\
\hline & 13 & & & 22.1 & 8.6 & 0.95 & 0.0 & -0.0 & 1.0 \\
\hline \multirow[t]{2}{*}{ Phe } & 12 & 59 & 51.9 & 51.9 & 5.0 & 0.96 & 0.0 & 0.1 & $16.0^{*}$ \\
\hline & 13 & & & 51.9 & 5.9 & 0.95 & 0.0 & -0.0 & 0.4 \\
\hline Thr & 12 & 59 & 97.4 & 97.8 & 4.6 & 0.98 & 0.6 & 0.2 & $50.6^{*}$ \\
\hline
\end{tabular}

${ }^{1}$ Equation [12] used the derived models for the portal-drained viscera (PDV) (Eq. [2]) and for the liver (LIV) (Eq. [9]) with the specified rate parameters from Table 4 and Table 8, respectively.

${ }^{2} \mathrm{~N}=$ number of observations.

${ }^{3} \mathrm{RMSE}=$ root mean squared error (\% of the observed mean).

${ }^{4} \mathrm{CCC}=$ concordance correlation coefficient.

$* P \leq 0.05$; otherwise, $P>0.05$.

\section{CONCLUSIONS}

Both PDV and LIV release of EAA can be accurately and precisely predicted based on absorbed EAA sup- plies given knowledge of arterial concentrations and blood flow. A combination of the 2 models predicted splanchnic release with high accuracy and precision, and can be used to predict total splanchnic EAA re-

Table 12. Statistical summary of splanchnic EAA fluxes $(\mathrm{mol} / \mathrm{d})$ predicted using the derived parameters from the combined portal-drained viscera (PDV) and liver (LIV) models

\begin{tabular}{|c|c|c|c|c|c|c|c|c|c|}
\hline EAA & Eq. ${ }^{1}$ & $\mathrm{~N}^{2}$ & $\begin{array}{l}\text { Observed } \\
\text { mean }\end{array}$ & $\begin{array}{l}\text { Predicted } \\
\text { mean }\end{array}$ & $\mathrm{RMSE}^{3}$ & $\mathrm{CCC}^{4}$ & $\begin{array}{l}\text { Mean bias } \\
(\% \text { MSE) }\end{array}$ & $\begin{array}{c}\text { Slope } \\
(\mathrm{mol} / \mathrm{mol})\end{array}$ & $\begin{array}{l}\text { Slope bias } \\
\text { (\% MSE) }\end{array}$ \\
\hline $\operatorname{Arg}$ & 12 & 22 & 3.1 & 3.1 & 5.3 & 0.97 & 0.3 & -0.1 & 5.6 \\
\hline His & 13 & & & 1.5 & 4.1 & 0.99 & 1.4 & 0.0 & $10.3^{*}$ \\
\hline \multirow[t]{2}{*}{ Ile } & 12 & 59 & 4.3 & 4.4 & 3.7 & 0.99 & 0.5 & 0.0 & $18.4^{*}$ \\
\hline & 13 & & & 4.4 & 3.8 & 0.99 & 1.2 & 0.1 & $29.0^{*}$ \\
\hline \multirow[t]{2}{*}{ Lys } & 12 & 59 & 2.9 & 2.9 & 6.2 & 0.99 & 0.2 & 0.1 & $25.4^{*}$ \\
\hline & 13 & & & 3.0 & 1.3 & 0.98 & 1.3 & 0.1 & $29.7^{*}$ \\
\hline \multirow[t]{2}{*}{ Met } & 12 & 59 & 0.8 & 0.8 & 7.9 & 0.98 & 1.4 & 0.1 & $19.2^{*}$ \\
\hline & 13 & & & 0.8 & 7.4 & 0.98 & 1.3 & 0.1 & $42.4^{*}$ \\
\hline \multirow[t]{2}{*}{ Phe } & 12 & 59 & 1.9 & 1.9 & 5.4 & 0.99 & 1.4 & 0.1 & $16.1^{*}$ \\
\hline & 13 & & & 1.9 & 5.1 & 0.99 & 0.5 & 0.1 & $16.9^{*}$ \\
\hline Thr & 12 & 59 & 3.5 & 3.5 & 3.3 & 0.99 & 0.6 & 0.0 & $20.7^{*}$ \\
\hline
\end{tabular}

${ }^{1}$ Equation [12] was using the derived models from Hanigan et al. (2004b) for the PDV and Hanigan et al. (1998b) for the LIV.

${ }^{2} \mathrm{~N}=$ number of observations.

${ }^{3} \mathrm{RMSE}=$ root mean squared error (\% of the observed mean).

${ }^{4} \mathrm{CCC}=$ concordance correlation coefficient.

${ }^{*} P \leq 0.05$; otherwise, $P>0.05$. 
lease, but with some linear bias. However, the models were not clearly superior to more empirical representations driven solely by absorbed EAA supply.

\section{ACKNOWLEDGMENTS}

This research was supported by funding provided, in part, by a USDA NIFA grant (Washington, DC; Award No: 2017-67015-26539); the Virginia Agricultural Experiment Station (Richmond, VA) and the Hatch Program of the National Institute of Food and Agriculture (Washington, DC), U.S. Department of Agriculture; Agriculture and Agri-Food Canada (Sherbrooke, Quebec), the College of Agriculture and Life Sciences Pratt Endowment at Virginia Tech (Blacksburg, VA); and Dairy Farmers of Canada, the Canadian Dairy Network, and the Canadian Dairy Commission under the Agri-Science Clusters Initiative (Ottawa, Ontario).

\section{REFERENCES}

Arriola Apelo, S. I., J. R. Knapp, and M. D. Hanigan. 2014. Invited review: Current representation and future trends of predicting amino acid utilization in the lactating dairy cow. J. Dairy Sci. 97:4000-4017.

Bach, A., G. B. Huntington, S. Calsamiglia, and M. D. Stern. 2000a. Nitrogen metabolism of early lactation cows fed diets with two different levels of protein and different amino acid profiles. J. Dairy Sci. 83:2585-2595.

Bach, A., G. B. Huntington, and M. D. Stern. 2000b. Response of nitrogen metabolism in preparturient dairy cows to methionine supplementation. J. Anim. Sci. 78:742-749.

Baird, G. D., H. W. Symonds, and R. Ash. 1974. Determination of portal and hepatic metabolite production rates in the adult dairy cow. Proc. Nutr. Soc. 33:70A-71A.

Baird, G. D., H. W. Symonds, and R. Ash. 1975. Some observations on metabolite production and utilization in vivo by the gut and liver of adult dairy cows. J. Agric. Sci. 85:281-296.

Benson, J. A., C. K. Reynolds, D. J. Humphries, S. M. Rutter, and D. E. Beever. 2001. Effects of abomasal infusion of long-chain fatty acids on intake, feeding behavior and milk production in dairy cows. J. Dairy Sci. 84:1182-1191.

Bequette, B. J., M. Hanigan, and H. Lapierre. 2003. Mammary uptake and metabolism of amino acids by lactating ruminants. Pages 347-365 in Amino Acids in Animal Nutrition. J. P. F. D’Mello, ed. CABI Publishing, Cambridge, MA.

Berthiaume, R., P. Dubreuil, M. Stevenson, B. W. McBride, and H Lapierre. 2001. Intestinal disappearance and mesenteric and portal appearance of amino acids in dairy cows fed ruminally protected methionine. J. Dairy Sci. 84:194-203.

Berthiaume, R., M. C. Thivierge, R. A. Patton, P. Dubreuil, M. Stevenson, B. W. McBride, and H. Lapierre. 2006. Effect of ruminally protected methionine on splanchnic metabolism of amino acids in lactating dairy cows. J. Dairy Sci. 89:1621-1634.

Bibby, J., and H. Toutenburg. 1978. Improved estimation and prediction. Z. Angew. Math. Mech. 58:45-49.

Blouin, J. P., J. F. Bernier, C. K. Reynolds, G. E. Lobley, P. Dubreuil, and H. Lapierre. 2002. Effect of supply of metabolizable protein on splanchnic fluxes of nutrients and hormones in lactating dairy cows. J. Dairy Sci. 85:2618-2630.

Casse, E., and H. Rulquin. 1993. Effects of dietary concentrates on the metabolism of energetic compounds in the portal-drained viscera (PDV) and in the liver in lactating dairy cows. Ann. Zootech. 42:206.
Casse, E. A., H. Rulquin, and G. B. Huntington. 1994. Effect of mesenteric vein infusion of propionate on splanchnic metabolism in primiparous Holstein cows. J. Dairy Sci. 77:3296-3303.

Dalbach, K. F., M. Larsen, B. M. L. Raun, and N. B. Kristensen 2011. Effects of supplementation with 2-hydroxy-4-(methylthio)butanoic acid isopropyl ester on splanchnic amino acid metabolism and essential amino acid mobilization in postpartum transition Holstein cows. J. Dairy Sci. 94:3913-3927.

De Visser, H., H. Valk, A. Klop, J. Van Der Meulen, J. G. M. Bakker, and G. B. Huntington. 1997. Nutrient fluxes in splanchnic tissue of dairy cows: Influence of grass quality. J. Dairy Sci. 80:1666-1673.

Delgado-Elorduy, A., C. B. Theurer, J. T. Huber, A. Alio, O. Lozano, M. Sadik, P. Cuneo, H. D. De Young, I. J. Simas, J. E. P. Santos, L. Nussio, C. Nussio, K. E. Webb Jr., and H. Tagari. 2002. Splanchnic and mammary nitrogen metabolism by dairy cows fed steam-rolled or steam-flaked corn. J. Dairy Sci. 85:160-168.

Dijkstra, J., H. D. S. C. Neal, D. E. Beever, and J. France. 1992. Simulation of nutrient digestion, absorption and outflow in the rumen: Model description. J. Nutr. 122:2239-2256.

Doepel, L., G. E. Lobley, J. F. Bernier, P. Dubreuil, and H. Lapierre. 2007. Effect of glutamine supplementation on splanchnic metabolism in lactating dairy cows. J. Dairy Sci. 90:4325-4333.

Doepel, L., G. E. Lobley, J. F. Bernier, P. Dubreuil, and H. Lapierre. 2009. Differences in splanchnic metabolism between late gestation and early lactation dairy cows. J. Dairy Sci. 92:3233-3243.

Ellis, J. L., C. K. Reynolds, L. A. Crompton, M. D. Hanigan, A. Bannink, J. France, and J. Dijkstra. 2016. Prediction of portal and hepatic blood flow from intake level data in cattle. J. Dairy Sci 99:9238-9253.

Estes, K. A. 2016. Assessing intestinal absorption of amino acids utilizing an isotope-based approach. MS Thesis. Department of Dairy Science, Virginia Polytechnic Institute and State University, Blacksburg, VA.

Fleming, A. J., H. Lapierre, R. R. White, H. Tran, P. J. Kononoff, R. Martineau, W. P. Weiss, and M. D. Hanigan. 2019. Predictions of ruminal outflow of amino acids in dairy cattle. J. Dairy Sci 102:10947-10963. https://doi.org/10.3168/jds.2019-16301.

Gibb, M. J., W. E. Ivings, M. S. Dhanoa, and J. D. Sutton. 1992 Changes in body components of autumn-calving Holstein-Friesian cows over the first 29 weeks of lactation. Anim. Prod. 55:339-360.

Girard, C. L., and A. Desrochers. 2010. Net flux of nutrients across splanchnic tissues of lactating dairy cows as influenced by dietary supplements of biotin and vitamin B12. J. Dairy Sci. 93:1644-1654.

Hammon, H. M., C. C. Metges, P. Junghans, F. Becker, O. Bellmann, F. Schneider, G. Nürnberg, P. Dubreuil, and H. Lapierre. 2008. Metabolic changes and net portal flux in dairy cows fed a ration containing rumen-protected fat as compared to a control diet. J. Dairy Sci. 91:208-217.

Hanigan, D. M. 2005. Quantitative aspects of ruminant splanchnic metabolism as related to predicting animal performance. Anim. Sci. 80:23-32.

Hanigan, M. D., J. P. Cant, D. C. Weakley, and J. L. Beckett. 1998a. An evaluation of postabsorptive protein and amino acid metabolism in the lactating dairy cow. J. Dairy Sci. 81:3385-3401.

Hanigan, M. D., L. A. Crompton, B. J. Bequette, J. A. N. Mills, and J. France. 2002. Modelling mammary metabolism in the dairy cow to predict milk constituent yield, with emphasis on amino acid metabolism and milk protein production: Model evaluation. J. Theor. Biol. 217:311-330.

Hanigan, M. D., L. A. Crompton, J. A. Metcalf, and J. France. 2001 Modelling mammary metabolism in the dairy cow to predict milk constituent yield, with emphasis on amino acid metabolism and milk protein production: Model construction. J. Theor. Biol. $213: 223-239$.

Hanigan, M. D., L. A. Crompton, C. K. Reynolds, D. Wray-Cahen, M A. Lomax, and J. France. 2004a. An integrative model of amino acid metabolism in the liver of the lactating dairy cow. J. Theor. Biol. 228:271-289.

Hanigan, M. D., J. France, L. A. Crompton, and B. J. Bequette. 2000. Evaluation of a representation of the limiting amino acid theory 
for milk protein synthesis. Pages 127-144 in Modelling Nutrient Utilization in Farm Animals. CABI, Wallingford, UK.

Hanigan, M. D., J. France, D. Wray-Cahen, D. E. Beever, G. E. Lobley, L. Reutzel, and N. E. Smith. 1998b. Alternative models for analyses of liver and mammary transorgan metabolite extraction data. Br. J. Nutr. 79:63-78.

Hanigan, M. D., C. K. Reynolds, D. J. Humphries, B. Lupoli, and J. D. Sutton. 2004b. A model of net amino acid absorption and utilization by the portal-drained viscera of the lactating dairy cow. J. Dairy Sci. 87:4247-4268.

Howarth, R. W., E. W. Boyer, W. J. Pabich, and J. N. Galloway. 2002. Nitrogen use in the United States from 1961-2000 and potential future trends. Ambio. 31:88-96.

Huntington, G. B. 1982. Portal blood flow and net absorption of ammonia-nitrogen, urea-nitrogen, and glucose in nonlactating Holstein cows. J. Dairy Sci. 65:1155-1162.

Huntington, G. B. 1984. Net absorption of glucose and nitrogenous compounds by lactating Holstein cows. J. Dairy Sci. 67:1919-1927.

Huntington, G. B., and P. J. Reynolds. 1986. Net absorption of glucose, l-lactate, volatile fatty acids, and nitrogenous compounds by bovine given abomasal infusions of starch or glucose. J. Dairy Sci 69:2428-2436.

Huntington, G. B., P. J. Reynolds, and H. F. Tyrrell. 1983. Net absorption and ruminal concentrations of metabolites in nonpregnant dry Holstein cows before and after intraruminal acetic acid infusion. J. Dairy Sci. 66:1901-1908.

Lapierre, H., D. R. Ouellet, R. Berthiaume, C. Girard, P. Dubreuil, M. Babkine, and G. E. Lobley. 2004. Effect of urea supplementation on urea kinetics and splanchnic flux of amino acids in dairy cows. J. Anim. Feed Sci. 13(Suppl. 1):319-322

Larsen, M., C. Galindo, D. R. Ouellet, G. Maxin, N. B. Kristensen, and H. Lapierre. 2015. Abomasal amino acid infusion in postpartum dairy cows: Effect on whole-body, splanchnic, and mammary amino acid metabolism. J. Dairy Sci. 98:7944-7961.

Larsen, M., and N. B. Kristensen. 2009. Effect of abomasal glucose infusion on splanchnic amino acid metabolism in periparturient dairy cows. J. Dairy Sci. 92:3306-3318.

Larsen, M., and N. B. Kristensen. 2012. Effects of glucogenic and ketogenic feeding strategies on splanchnic glucose and amino acid metabolism in postpartum transition Holstein cows. J. Dairy Sci. 95:5946-5960.

Lin, L. I.-K. 1989. A concordance correlation coefficient to evaluate reproducibility. Biometrics 45:255-268.

Lobley, G. E. 2003. Protein turnover-What does it mean for animal production? Can. J. Anim. Sci. 83:327-340.

Lomax, M. A., and G. D. Baird. 1983. Blood flow and nutrient exchange across the liver and gut of the dairy cow. Br. J. Nutr. 49:481-496.

MacRae, J. C., L. A. Bruce, D. S. Brown, and A. G. Calder. 1997a. Amino acid use by the gastrointestinal tract of sheep given lucerne forage. Am. J. Physiol. 273:G1200-G1207.

MacRae, J. C., L. A. Bruce, D. S. Brown, D. A. Farningham, and M. Franklin. 1997b. Absorption of amino acids from the intestine and their net flux across the mesenteric- and portal-drained viscera of lambs. J. Anim. Sci. 75:3307-3314.

McGuire, M. A., D. K. Beede, M. A. DeLorenzo, C. J. Wilcox, G. B. Huntington, C. K. Reynolds, and R. J. Collier. 1989. Effects of thermal stress and level of feed intake on portal plasma flow and net fluxes of metabolites in lactating Holstein cows1,2,3. J. Anim. Sci. 67:1050-1060.

Newsholme, E. and T. Leech. 1983. Functional Biochemistry in Health and Disease. Wiley-Blackwell, West Sussex, UK.

NRC (National Research Council). 2001. Nutrient Requirements of Dairy Cattle. 7th ed. Natl. Acad. Press, Washington, DC.

Paz Manzano, H. A., E. Castillo-Lopez, T. J. Klopfenstein, and P. J. Kononoff. 2014. Ruminal degradation and intestinal digestibility of crude protein and amino acids and correction for microbial contamination in rumen-undegradable protein. J. Anim. Sci. 92 (E-Suppl. 2).
R Core Team. 2015. R: A language and environment for statistical computing. R Foundation for Statistical Computing, Vienna, Austria

Raggio, G., D. Pacheco, R. Berthiaume, G. E. Lobley, D. Pellerin, G. Allard, P. Dubreuil, and H. Lapierre. 2004. Effect of level of metabolizable protein on splanchnic flux of amino acids in lactating dairy cows. J. Dairy Sci. 87:3461-3472.

Reynolds, C. K. 2006. Splanchnic metabolism of amino acids in ruminants. Pages 225-248 in Ruminant Physiology: Digestion, Metabolism and Impact of Nutrition on Gene Expression, Immunology and Stress. K. Sejrsen, T. Hvelplund, and M. O. Nielsen, ed. Academic Publishers, Wageningen, the Netherlands.

Reynolds, C. K., P. C. Aikman, B. Lupoli, D. J. Humphries, and D. E. Beever. 2003a. Splanchnic metabolism of dairy cows during the transition from late gestation through early lactation. J. Dairy Sci. $86: 1201-1217$

Reynolds, C. K., J. A. Benson, P. C. Aikman, B. Lupoli, M. D. Hanigan, D. E. Beever, and J. C. MacRae. 2003b. Effects of diet forage: concentrate ratio on splanchnic nutrient metabolism in lactating dairy cows. J. Dairy Sci. 86:219. (Abstr.)

Reynolds, C. K., B. J. Bequette, J. S. Caton, D. J. Humphries, P. C Aikman, B. Lupoli, and J. D. Sutton. 2001. Effects of intake and lactation on absorption and metabolism of leucine and phenylalanine by splanchnic tissues of dairy cows. J. Dairy Sci. 86:362 (Abstr.)

Reynolds, C. K., L. A. Crompton, K. Firth, D. E. Beever, J. D. Sutton, M. A. Lomax, D. Wray-Cahen, J. A. Metcalf, E. Chettle, C. Backwell, B. J. Bequette, G. E. Lobley, and J. C. MacRae. 1995. Splanchnic and milk protein responses to mesenteric vein infusion of 3 mixtures of amino acids in lactating dairy cows. J. Anim. Sci. 73:274. (Abstr.)

Reynolds, C. K., B. Dürst, B. Lupoli, D. J. Humphries, and D. E. Beever. 2004. Visceral tissue mass and rumen volume in dairy cows during the transition from late gestation to early lactation. J. Dairy Sci. 87:961-971.

Reynolds, C. K., D. J. Humphries, J. A. Benson, and D. E. Beever. 1998. Effects of abomasal maize starch infusion on splanchnic metabolism and milk production in dairy cows. J. Anim. Sci. 76 (Suppl. 1):310. (Abstr.)

Reynolds, C. K., D. J. Humphries, S. B. Cammell, J. A. Benson, J. D. Sutton, and D. E. Beever. 1997. Effects of abomasal wheat starch infusion on splanchnic metabolism and energy balance of lactating dairy cows. In Energy Metabolism of Farm Animals. Proceedings of the 14th Symposium on Energy Metabolism. K. J. McCracken, E. F. Unsworth, and A. R. G. Wylie, ed. CAB International, Wallingford, UK

Reynolds, C. K., G. B. Huntington, H. F. Tyrrell, and P. J. Reynolds, 1988. Net portal-drained visceral and hepatic metabolism of glucose, l-lactate, and nitrogenous compounds in lactating Holstein cows. J. Dairy Sci. 71:1803-1812.

Reynolds, C. K., B. Lupoli, P. C. Aikman, J. A. Benson, D. J. Humphries, L. A. Crompton, J. D. Sutton, J. France, D. E. Beever, and J. C. MacRae. 1999. Effects of abomasal casein or essential amino acid infusions on splanchnic metabolism in lactating dairy cows. J. Anim. Sci. 77:266. (Abstr.)

Røjen, B. A., P. Lund, and N. B. Kristensen. 2008. Urea and shortchain fatty acids metabolism in Holstein cows fed a low-nitrogen grass-based diet. Animal. 2:500-513.

Røjen, B. A., B. M. L. Raun, P. Lund, and N. B. Kristensen. 2004 Effect of supplement strategy on splanchnic net fluxes of ammonia and urea in dairy cows fed fresh grass. J. Anim. Feed Sci. 13(Suppl. 1):347-350.

Shimomura, Y., T. , M. Honda, T. Shiraki, J. Murakami, H. Sato, K. Kobayashi, M. Mawatari, Obayashi, and R. A. Harris. 2006. Branched-chain amino acid catabolism in exercise and liver disease. J. Nutr. 136:250S-253S.

Sok, M., D. R. Ouellet, J. L. Firkins, D. Pellerin, and H. Lapierre. 2017. Amino acid composition of rumen bacteria and protozoa in cattle. J. Dairy Sci. 100:5241-5249. 
Tagari, H., K. Webb Jr., B. Theurer, T. Huber, P. Cuneo, D. DeYoung, A. Delgado-Elorduy, M. Sadik, A. Alio, O. Lozano, J. Simas, L. Nussio, C. Nussio, P. Pu, F. Santos, and J. E. P. Santos. 2000. Portal-drained visceral flux (PDVF) and mammary uptake (MU) of free (FAA) and peptide-bound amino acids (PBAA) in lactating cows fed diets containing steam flaked (SFS) or dry rolled (RDS) sorghum. J. Dairy Sci. 83:267. (Abstr.)

Tagari, H., K. Webb Jr., B. Theurer, T. Huber, D. DeYoung, P. Cuneo, J. E. P. Santos, J. Simas, M. Sadik, A. Alio, O. Lozano, A. Delgado-Elorduy, L. Nussio, C. M. M. Bittar, and F. Santos. 2008. Mammary uptake, portal-drained visceral flux, and hepatic metabolism of free and peptide-bound amino acids in cows fed steamflaked or dry-rolled sorghum grain diets. J. Dairy Sci. 91:679-697.

Tagari, H., K. Webb Jr., B. Theurer, T. Huber, D. DeYoung, P. Cuneo, J. E. P. Santos, J. Simas, M. Sadik, A. Alio, O. Lozano, A. Delgado-Elorduy, L. Nussio, C. Nussio, and F. Santos. 2004. Portal drained visceral flux, hepatic metabolism, and mammary uptake of free and peptide-bound amino acids and milk amino acid output in dairy cows fed diets containing corn grain steam flaked at 360 or steam rolled at $490 \mathrm{~g} / \mathrm{L}$. J. Dairy Sci. 87:413-430.

Tamminga, S., H. Schulze, J. Van Bruchem, and J. Huisman. 1995. The nutritional significance of endogenous N-losses along the gastrointestinal tract of farm animals. Arch. Tierernahr. 48:9-22.

White, R. R., P. J. Kononoff, and J. L. Firkins. 2017a. Technical note: Methodological and feed factors affecting prediction of ruminal degradability and intestinal digestibility of essential amino acids. J. Dairy Sci. 100:1946-1950.

White, R. R., T. McGill, R. Garnett, R. J. Patterson, and M. D. Hanigan. 2017b. Short communication: Evaluation of the PREP10 energy-, protein-, and amino acid-allowable milk equations in comparison with the National Research Council model. J. Dairy Sci 100:2801-2806.

Whitt, J., G. Huntington, E. Zetina, E. Casse, K. Taniguchi, and W. Potts. 1996. Plasma flow and net nutrient flux across gut and liver of cattle fed twice daily. J. Anim. Sci. 74:2450-2461.

Wray-Cahen, D., J. A. Metcalf, F. R. C. Backwell, B. J. Bequette, D. S. Brown, J. D. Sutton, and G. E. Lobley. 1997. Hepatic response to increased exogenous supply of plasma amino acids by infusion into the mesenteric vein of Holstein-Friesian cows in late gestation. Br. J. Nutr. 78:913-930

\section{ORCIDS}

A. J. Fleming () https://orcid.org/0000-0002-6122-5962

H. Lapierre (® https://orcid.org/0000-0002-1162-7226

M. D. Hanigan ( https://orcid.org/0000-0002-5639-9677 